\title{
ANÁLISE DA LEI DE ALIMENTOS GRAVÍDICOS
}

\section{ANALYSES OF THE UNBORN CHILD SUPPORT}

\section{LAW}

Fernanda Carolina Cerqueira Lopes ${ }^{1}$

Camilo de Lelis Colani Barbosa²

Resumo: Com a vigência da lei ainda permanecem em voga no sob o n. ${ }^{\circ}$ 11.804/2008, ocorreu cenário doutrinário e jurisprua regulamentação dos alimentos dencial, como por exemplo, os gravídicos. A questão dos ali- indícios de paternidade, a legitimentos sempre foi acentuada- midade ativa e passiva, o termo mente discutida, especialmente, inicial, a (ir)retroatividade dos atinente aos direitos do nascituro, alimentos gravídicos diante da por isso, o instituto legal referido não concessão e posterior comfoi essencial, para amparar tais provação de paternidade, a (im) direitos. Neste contexto, vislum- possibilidade de exigência dos bram-se incongruências na citada danos materiais e/ou morais pelo

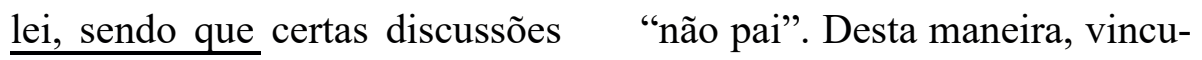
1 Bacharela do curso de Direito da UCSal - Universidade Católica do Salvador. Pós-graduanda em Direito Médico e Bioética pela PUC/ MG - Pontifícia Universidade Católica de Minas Gerais

2 Possui graduação (1992), mestrado (1996) e doutorado (2003) pela PUC/SP - Pontifícia Universidade Católica de São Paulo. Foi professor da PUC/SP de 1992 a 2015. Atualmente é professor adjunto da Faculdade Baiana de Direito. Professor da UCSal - Universidade Católica do Salvador, nos cursos de graduação, mestrado e doutorado. É advogado com área de atuação profissional em Direito Civil. Presidente Regional (Bahia) da ADFAS - Associação de Direito da Família e das Sucessões

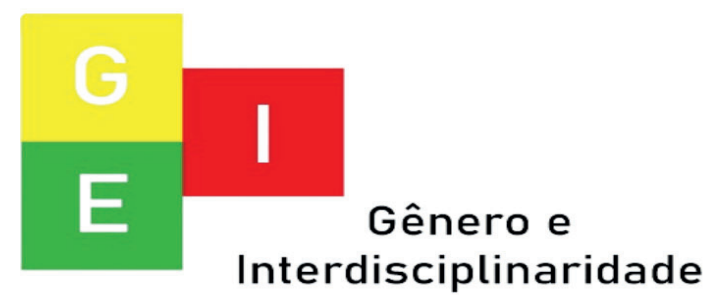


ISSN: 2675-7451

Vol. 02 - n 03 - ano 2021

Editora Acadêmica Periodicojs

la-se a direitos fundamentais e princípios basilares do ordenamento jurídico pátrio, tais como a dignidade da pessoa humana, o direito à vida, o melhor interesse da criança, a paternidade responsável, a solidariedade familiar e a posição jurídica do nascituro.

Palavras-chave: Alimentos Gravídicos. Nascituro.

Abstract: The regulation of the unborn child support occured after the enactment of the law n. ${ }^{\circ}$ 11.804/2008. The issue of child support has always been vastly discussed, especially when it is related to the rights of unborn children. The referred legal institut was therefore essential to support those rights. In this context, it is possible to identify the inconsistencies of this law. Certain discussions are still in vogue in this doctriary and jurisprudencial area, such as paternity eviden-

ces, active and passive legitimation, the inicial terme, the (non) retroactivity of unborn child support facing non concession and posterior proof of paternity, the (im)possibility of demanding compensation for material and/ or moral damage concerning the "non-father". It is linked thus to the fundamental rights and fundamental principles within the national legal core, such as human dignity, the right to life, the best interest of a child, responsible fatherhood, family solidarity and the legal position of unborn children.

Keywords: Unborn Child Support. Unborn Child.

\section{INTRODUÇÃO}

A história registra que desde que o homem é homem

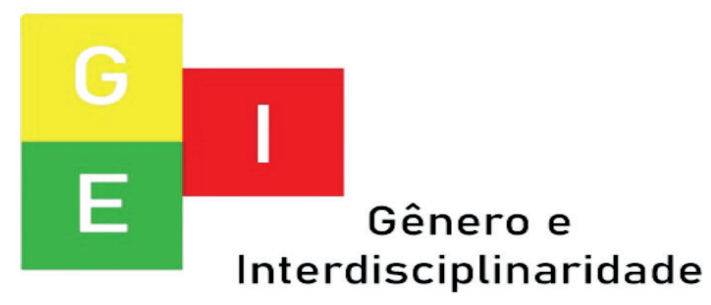


ISSN: 2675-7451

Vol. 02 - n 03 - ano 2021

Editora Acadêmica Periodicojs

sempre precisou de proteção e ajuda por parte de seus semelhantes. Com o decurso do tempo, apesar de ter evoluído em uma série de aspectos, adicionando-se outras necessidades não exigíveis em épocas pretéritas, alguns requisitos básicos essenciais à sobrevivência permanecem inalterados, como a necessidade de alimentos, que abrange, além do sustento, a educação, o vestuário, a saúde, a moradia.

No cenário contemporâneo, inúmeras pessoas não alcançam sozinhas, os meios essenciais para a promoção da própria subsistência. Dessa forma, cabe precipuamente a entidade familiar, especialmente aos pais o dever de cuidar e prestar alimentos. Entretanto, o ente estatal também tem o fito de promover o bem-estar da sociedade e, amparar estes indivíduos por meio de suas atividades assistencialistas.

$$
\text { Pelo exposto, é crível se }
$$

observar a essencialidade dos alimentos, principalmente aqueles destinados ao nascituro, que é o ponto de partida do nosso estudo. Assim, cumpre salientar que anteriormente ao advento da Lei 11.804 de 5 de novembro de 2008, não havia um amparo legal expresso acerca dos alimentos gravídicos e suas repercussões. Com a citada lei, a proteção ao nascituro tornou-se latente, mas ainda há algumas lacunas que dão luz a certos embates doutrinários e jurisprudenciais.

Antes de adentrar nas incongruências legais, faz-se um breve apanhado sobre as teorias da personalidade civil, e enfatiza-se a corrente concepcionista, que realiza a quebra de paradigma do nascituro de mero expectador a sujeito de direitos, o que está especialmente atrelado ao

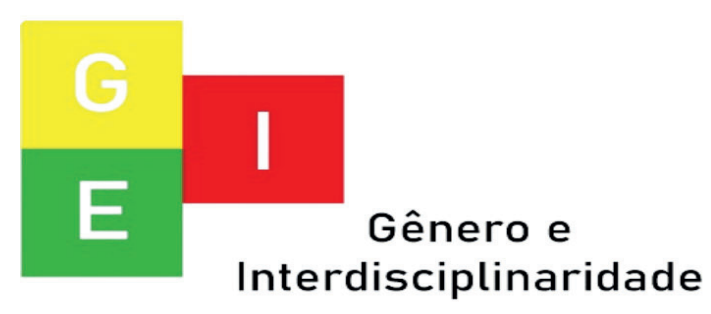


ISSN: 2675-7451

Vol. 02 - n 03 - ano 2021

Editora Acadêmica Periodicojs

Pacto de São José da Costa Rica ${ }^{1}$, o qual defende o direito à vida desde o momento da concepção, sendo o Brasil signatário. Como também, será delineado acerca do nascituro e o seu direito aos alimentos; e sobre os princípios constitucionais basilares que regem o ordenamento pátrio no cerne do direito de família que visam amparar o nascituro, como a dignidade da pessoa humana, a paternidade responsável, a solidariedade familiar e o melhor interesse da criança.

Nesse diapasão, o objetivo principal do presente trabalho é apontar as incongruências da lei de alimentos gravídicos, como por exemplo os indícios de paternidade, a legitimidade ativa 1 O tratado, também chamado de Pacto de San José da Costa Rica, foi assinado em 22 de novembro de 1969 , na cidade de San José, na Costa Rica, e ratificado pelo Brasil em setembro de 1992. e passiva, o termo inicial, a (ir) retroatividade dos alimentos gravídicos diante da não concessão e posterior comprovação de paternidade, a (im)possibilidade de exigência dos danos materiais e/ ou morais pelo "não pai".

Para tanto, o método utilizado foi o dedutivo, partindo do estudo do nascituro e seus direitos, e depois da própria lei de alimentos gravídicos e nas suas incongruências. Por fim, o método de procedimento em questão foi o de revisão bibliográfica, cujas fontes compreendem pesquisas em livros, revistas científicas, sítios da internet, jurisprudências, entre outras.

Portanto, a partir deste estudo se infere que o instituto em análise demonstra eloquente importância no cunho dos vínculos jurídicos familiares e almeja implementar princípios e matizes constitucionais, resguardando

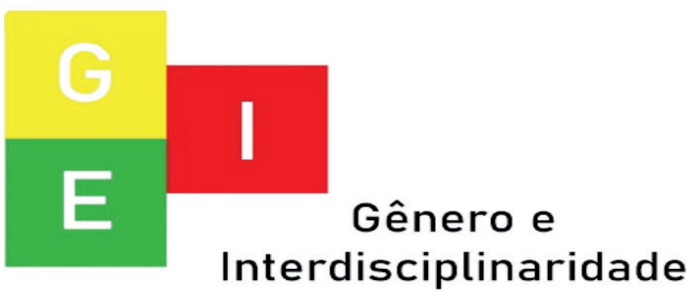


Vol. 02 - n 03 - ano 2021

Editora Acadêmica Periodicojs

aos indivíduos direitos essenciais à vida digna, do que desponta o alcance social e a relevância jurídica da pesquisa científica objeto deste trabalho.

O NASCITURO E SUA TUTELA JURÍDICA: DE MERO EXPECTADOR A SUJEITO DE DIREITOS

Além do disposto na nossa Carta Magna, art. $5^{\circ}$ caput, o direito à vida que se estende à vida do nascituro é resguardado no art. $4^{\circ}$, Seção I, da Declaração Universal dos Direitos Humanos (Pacto de São José da Costa Rica), da qual o Estado Brasileiro é signatário, e que engloba o direito à vida desde a concepção, observa-se, "Direito à vida: 1 . Toda pessoa tem o direito de que se respeite sua vida. Esse direito deve ser protegido pela lei e, em geral, desde o momento da con- cepção. Ninguém pode ser privado da vida arbitrariamente. "

Nesta senda, além do direito à vida, o STJ já vem concedendo uma gama de direitos aos ainda não nascidos. Pode-se citar, o direito à honra, ao nome, à imagem, à integridade moral e psíquica, etc, que são considerados de cerne extrapatrimonial. Como também, há os de esfera patrimonial, por exemplo a doação ${ }^{2}$, a herança ${ }^{3}$, a sucessão testamentária ${ }^{4}$.

2 Art. 542 do CC/02 - "A doação feita ao nascituro valerá, sendo aceita pelo seu representante legal.

3 Art. 1.798 do CC/02 -

"Legitimam-se a suceder as pessoas nascidas ou já concebidas no momento da abertura da sucessão". 4 Art. 1.799 do CC/02 "Na sucessão testamentária podem ser chamados ainda a suceder: I - os filhos, ainda não

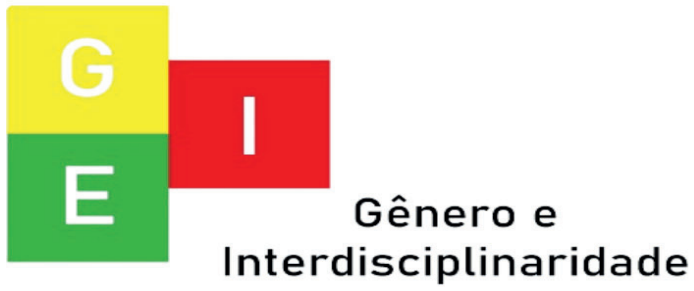


ISSN: 2675-7451

Vol. 02 - n 03 - ano 2021

Editora Acadêmica Periodicojs

A polêmica surge no "inexoravelmente vinculados".

que tange à personalidade civil, visto que o $\mathrm{CC} / 02$ no seu art. $2^{\circ}$, prescreve que "a personalidade civil começa do nascimento com vida, mas a lei põe a salvo, desde a concepção os direitos do nascituro", ou seja, à primeira vista, em uma leitura simplista e literal, não contempla o nascituro como titular da dita personalidade. Dessa forma, há três linhas doutrinárias que remetem a temática do nascituro, tais quais: a natalista, a concepcionista e a da personalidade condicional.

A teoria que é alcunhada de natalista, adotada a título de exemplo por Caio Mário da Silva Pereira, Sílvio Venosa e San Tiago Dantas, sustenta que a titularização de direitos e a personalidade jurídica são conceitos concebidos, de pessoas indicadas pelo testador, desde que vivas estas ao abrir-se a sucessão. ”
Deste modo, se o CC/02 não reconhece a personalidade jurídica ao nascituro, esse também não pode ser considerado como titular de direitos. Assim, o ser que ainda não nasceu, teria somente "mera expectativa de direitos".

A vertente concepcionista, aduz que a dita personalidade é oriunda da concepção. Desse modo, o nascituro é tido como titular de direitos, ainda que certos direitos só possam ser plenamente executáveis com o nascimento, como os atinentes à herança, legado e doação. Adotam esse segmento: Pablo Stolze/ Rodolfo Pamplona, Maria Berenice Dias, Silmara Chinellato, entre outros.

A terceira e última corrente, que é chamada de teoria da personalidade condicional, traz que a citada personalidade começa com a concepção, mas

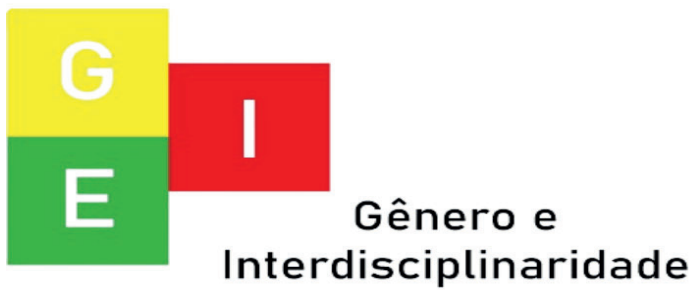


ISSN: 2675-7451

Vol. 02 - n 03 - ano 2021

Editora Acadêmica Periodicojs

fica sujeita a uma condição sus-

pensiva (o nascimento com vida), resguardados, sem embargo, desde a concepção, os direitos da personalidade, especialmente os que estão destinados a garantir o nascimento (vide, por exemplo Arnaldo Rizzardo e Clóvis Beviláqua).

Como bem exprimem, os Ministros do STJ, Marco Buzzi e Luis Felipe Salomão, respectivamente:

[..] inequívoco avanço, na doutrina, assim como na jurisprudência, acerca da proteção dos direitos do nascituro. A par das teorias que objetivam definir, com precisão, o momento em que o indivíduo adquire personalidade jurídica, assim compreendida como a capacidade de titularizar direitos e obrigações, é certo que o nascituro, ainda que considerado como realidade jurídica distinta da pessoa natural, é, igualmente, titular de direitos da personalidade (ao menos reflexamente). GRIFO NOSSO. (Recurso Especial do STJ sob o $n^{\circ}$ : 1.170.239 - RJ 2009/0240262-7. Relator: Min. Marco Buzzi. Data do julgamento: 28/08/2013) 1. A despeito da literalidade do art. $2^{\circ}$ do Código Civil - que condiciona a aquisição de personalidade jurídica ao nascimento - , o ordenamento jurídico pátrio aponta sinais de que não há essa indissolúvel vinculação entre o nascimento com vida e o conceito de pessoa, de personalidade jurídica e de titularização de direitos, como pode aparentar a leitura mais simplificada da lei. [...] 3.

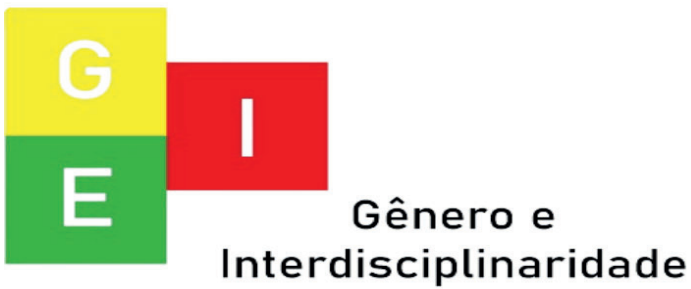


ISSN: 2675-7451

Vol. 02 - n 03 - ano 2021

Editora Acadêmica Periodicojs

As teorias mais restritivas dos direitos do nascituro - natalista e da personalidade condicional - fincam raízes na ordem jurídica superada pela Constituição Federal de 1988 e pelo Código Civil de 2002. O paradigma no qual foram edificadas transitava, essencialmente, dentro da órbita dos direitos patrimoniais. Porém, atualmente isso não mais se sustenta. Reconhecem-se, corriqueiramente, amplos catálogos de direitos não patrimoniais ou de bens imateriais da pessoa - como a honra, o nome, imagem, integridade moral e psíquica, entre outros. 4. Ademais, hoje, mesmo que se adote qualquer das outras duas teorias restritivas, há de se reconhecer a titularidade de direitos da personalidade ao nascituro, dos quais o direito à vida é o mais importante. Garantir ao nascituro expectativas de direitos, ou mesmo direitos condicionados ao nascimento, só faz sentido se lhe for garantido também o direito de nascer, o direito à vida, que é direito pressuposto a todos os demais." GRIFO NOSSO. (Recurso Especial do STJ sob o n ${ }^{0}: 1.415 .727$ - SC 2013/0360491-3. Relator: Min. Luis Felipe Salomão. Data do julgamento: 29/09/2014)

Logo, resta cristalino que a teoria que melhor ampara o nascituro é a concepcionista, pois trata o ser que habita no útero materno, não como um mero expectador de direitos, mas como um nato e verdadeiro titular des-

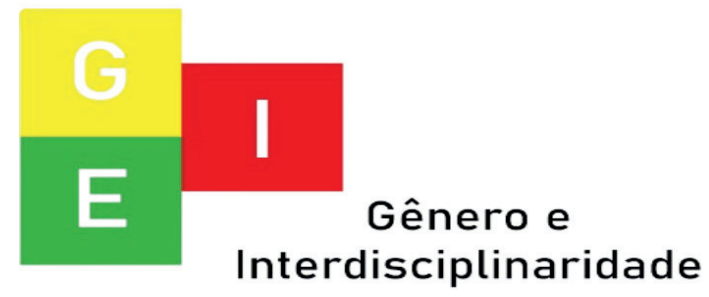


ISSN: 2675-7451

Vol. 02 - n 03 - ano 2021

Editora Acadêmica Periodicojs

tes. Haja vista que, o nascituro

merece ter seus direitos respeitados e tem direito a ver sua expectativa do nascimento se realizar de maneira digna.

O NASCITURO E O DIREITO AOS ALIMENTOS

$\mathrm{O}$ direito do nascituro aos alimentos está umbilicalmente atrelado ao direito à vida, que se abrange à vida do nascituro, que consta no art. $5^{\circ}$, caput da $\mathrm{CF} / 88$ e, no art. $4^{\circ}$, Seção I do Pacto de São José da Costa Rica. Visto que, não há um desenvolvimento digno e saudável no meio intrauterino e o corolário nascimento com vida, sem a devida concessão dos alimentos ao nascituro, que está amparado de forma expressa no art. 227 , caput $^{5} \mathrm{da}$

5 Art. 227, caput da CF/88 - "É dever da família, da sociedade e do Estado assegurar criança,
Carta Magna.

$\mathrm{O}$ art. $2^{\circ}$ do CC/02 alinhou-se mais a corrente concepcionista e, dispõe que a personalidade jurídica do homem está atrelada ao nascimento com vida, mas salvaguarda desde a concepção os direitos dos ainda não nascidos. Dessa forma, sem sombra de dúvidas denota que o nascituro não só precisa ser amparado, como tem direito aos alimentos.

Neste diapasão, elucida Cahali:

Desde o momento da concepção, o ser humano - por sua es-

ao adolescente e ao jovem, com absoluta prioridade, o direito à vida, à saúde, à alimentação, à educação, ao lazer, à profissionalização, à cultura, à dignidade, ao respeito, à liberdade e à convivência familiar e comunitária, além de colocá-los a salvo de toda forma de negligência, discriminação, exploração, violência, crueldade e opressão. "

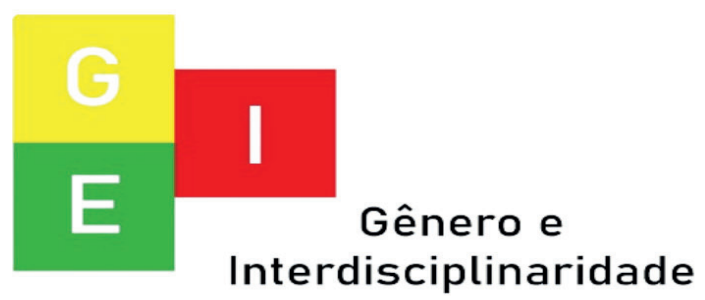


ISSN: 2675-7451

Vol. 02 - n 03 - ano 2021

Editora Acadêmica Periodicojs

trutura e natureza - é um ser carente por excelência; ainda no colo materno, ou já fora dele, a sua incapacidade ingênita de produzir meios necessários à sua manutenção faz com que se lhe reconheça, por um princípio natural jamais questionado, o superior direito de ser nutrido pelos responsáveis por sua geração. (CAHALI, 2007, p. 29)

Partindo deste entendimento, clarividente que a teoria concepcionista é a que melhor se adapta a realidade contemporânea e a que de fato protege o direito do nascituro aos alimentos. Tendo em vista que, no viés da teoria natalista o direito alimentar só poderia ser concedido se ocorresse o nascimento com vida do nascituro, o que não merece guarida no nosso ordenamento jurídico pátrio.

Crível destacar, que por demasiado lapso temporal o direito do nascituro aos alimentos permaneceu no limbo, sem um instituto legal específico. Porém, em 05 de novembro de 2008 foi promulgada a Lei 11.804, que trata acerca dos citados alimentos.

Nesta senda, como bem define Rolf Madaleno:

Os alimentos gravídicos representam uma pensão alimentícia $[. .$.$] para cobrir$ as despesas adicionais do período de gravidez e que sejam dela decorrentes no período compreendido entre a concepção e o parto, inclusive as despesas referentes à alimentação especial, assistência médica e psicológica, exames complementares, internações, parto, medicamentos e demais prescrições preventivas e tera-

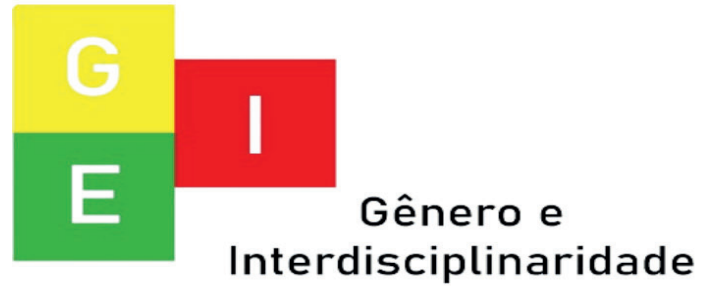


ISSN: 2675-7451

Vol. 02 - n 03 - ano 2021

Editora Acadêmica Periodicojs

pêuticas indispensáveis, conforme prescrição médica (Lei 11.804/2008, art. $2^{\circ}$ ) [...]. (MADALENO, 2019, p. 77)

Assim, os alimentos ao nascituro deverão ser custeados pelo futuro pai, como também pela mulher grávida, de acordo com o binômio possibilidade-necessidade, como aduz o art. $2^{\circ}$, parágrafo único da lei de alimentos gravídicos.

Portanto, o direito do nascituro aos alimentos está sob a égide constitucional, civilista, em tratado internacional e em legislação específica própria, haja vista que visa à dignidade do nascituro, viabilizando e assegurando ao alimentado, meios para subsistir.

O NASCITURO E OS PRINCÍPIOS CONSTITUCIONAIS

\section{QUE AO SEU REDOR GRA- VITAM}

A lei de Alimentos Gravídicos é um instrumento protecionista dos direitos fundamentais do nascituro, dessa maneira tem como norte alguns princípios constitucionais, em especial a dignidade da pessoa humana, a paternidade responsável, a solidariedade familiar e o melhor interesse da criança.

\section{DIGNIDADE DA PESSOA HUMANA}

O princípio da Dignidade da Pessoa Humana, também alcunhado pela doutrina como macro princípio ou superprincípio (SIMÃO; TARTUCE, 2011, p. 34), está expresso no art. $1^{\circ}$, III da $\mathrm{CF} / 88$. Ele é o pilar que norteia todas as relações jurídicas, e trazendo para o nosso cerne de

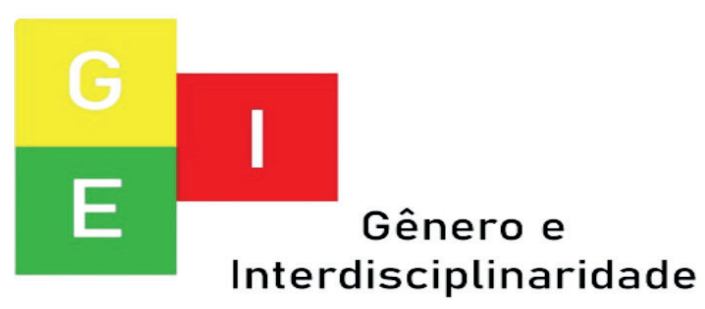


ISSN: 2675-7451

Vol. 02 - n 03 - ano 2021

Editora Acadêmica Periodicojs

estudo, é inegável dizer que ele está presente no âmbito da dignificação do nascituro.

Nesta senda, resta cristalino que o dito princípio, repercute na própria dignidade do nascituro, visto que este necessita da prestação dos alimentos gravídicos, no mínimo existencial necessário para a manutenção da sua vida humana que se encontra em formação. Vale destacar, que cabe ao ente estatal a concretização da dignidade do nascituro através da concessão de alimentos, o que está diretamente atrelado com a ideia de eficácia vertical dos direitos fundamentais.

Outro ponto importante é que o princípio supracitado é parâmetro para a fixação dos alimentos gravídicos, haja vista que estes são determinados conforme a possibilidade daquele que fornece, e com a necessidade daquele que os pleiteia, o chama- do binômio necessidade- possi-

bilidade. Assim na fixação do quantum alimentar, este princípio deve ser respeitado.

Portanto, os alimentos gravídicos em consonância com a dignidade da pessoa humana e de acordo com o binômio possibilidade-necessidade almejam a promoção de uma gestação sadia até o nascimento com vida, que posteriormente são convertidos em pensão alimentícia. Para que, o nascituro possa de fato tornar-se um indivíduo completo digno de sua própria existência.

\section{PATERNIDADE RESPONSÁ-} VEL

O princípio da paternidade responsável está disposto expressamente no art. $226^{6}, \S 7^{\circ}$

6 Art. $226, \S 7^{\circ}$ da $\mathrm{CF} / 88$ - "A família, base da sociedade, tem especial proteção do Estado.

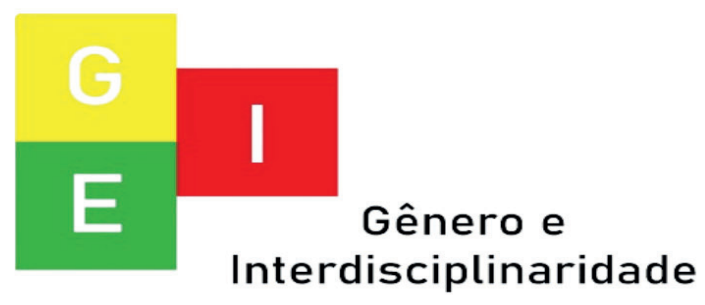


ISSN: 2675-7451

Vol. 02 - n 03 - ano 2021

Editora Acadêmica Periodicojs

da $\mathrm{CF} / 88$, sendo que pode ser interpretado sob o aspecto da autonomia para decidir o planejamento familiar ou do prisma da responsabilidade dos pais para com os filhos, isto é, o dever parental. Sendo que, o presente estudo está sob a segunda interpretação.

Importa salientar, que o dito princípio também está nas entrelinhas delineado nos arts. 227, caput e $229^{7}$ da CF/88. Sen-

$\S 7^{\circ}$ Fundado nos princípios da dignidade da pessoa humana e da paternidade responsável, o planejamento familiar é livre decisão do casal, competindo ao Estado propiciar recursos educacionais e científicos para o exercício desse direito, vedada qualquer forma coercitiva por parte de instituições oficiais ou privadas" 7 Art. 229 da CF/88 - "Os pais têm o dever de assistir, criar e educar os filhos menores, e os filhos maiores têm o dever de do que, no âmbito dos alimentos gravídicos a paternidade responsável é essencial, pois a mãe e o suposto genitor são responsáveis pela alimentação do nascituro, que vai além dos alimentos propriamente ditos, como também engloba consultas médicas, medicamentos, entre outros.

Isto posto, nota-se que os alimentos do nascituro estão diretamente atrelados ao princípio da paternidade responsável.

\section{SOLIDARIEDADE FAMI-}

\section{LIAR}

O princípio da solidariedade familiar está disposto em alguns arts. da $\mathrm{CF} / 88$, sendo eles o $3^{\text {o }}$, inciso $I^{8}$, 227, caput, 229. ajudar e amparar os pais na velhice, carência ou enfermidade." 8 Art. $3^{\circ}$, I da $\mathrm{CF} / 88$ "Constituem objetivos fundamentais da República Federativa

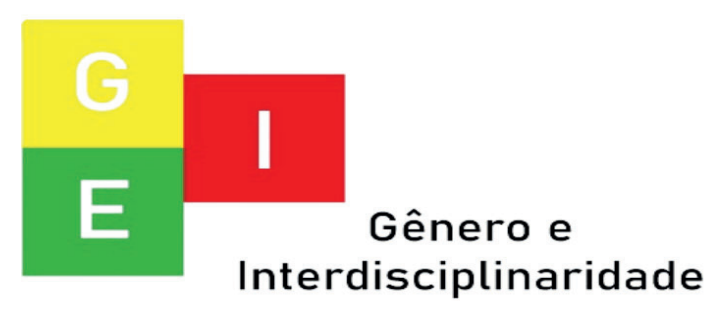


ISSN: 2675-7451

Vol. 02 - n 03 - ano 2021

Editora Acadêmica Periodicojs

Dessa forma, o direito a alimentos, em especial os gravídicos são embasados por este princípio, que traduz respeito e consideração mútuos entre os familiares, consoante ensinamento de Carlos Roberto Gonçalves:

"O dever de prestar alimentos funda-se na solidariedade humana e econômica que deve existir entre os membros da família ou parentes. Há "um dever legal de mútuo auxílio familiar, transformado em norma, ou mandamento jurídico. Originariamente, não passava de um dever moral, ou uma obrigação ética, que no direito romano se expressava na equidade, ou no officium pietatis, ou nas caritas. No entanto, as razões que obrigam a sustentar os paren-

do Brasil: I - construir uma sociedade livre, justa e solidária [...]”. tes e a dar assistência ao cônjuge transcendem as simples justificativas morais ou sentimentais, encontrando sua origem no próprio direito natural"." (GONÇALVES,2017, p. 653654)

Sílvio de Salvo Venosa, também aduz sobre a solidariedade familiar:

Em linha fundamental, quem não pode prover a própria subsistência nem por isso deve ser relegado ao infortúnio. A pouca idade, a velhice, a doença, a falta de trabalho ou qualquer incapacidade pode colocar a pessoa em estado de necessidade alimentar. A sociedade deve prestar-lhe auxílio. $\mathrm{O}$ Estado designa em primeiro lugar os parentes para fazê-lo, aliviando em parte

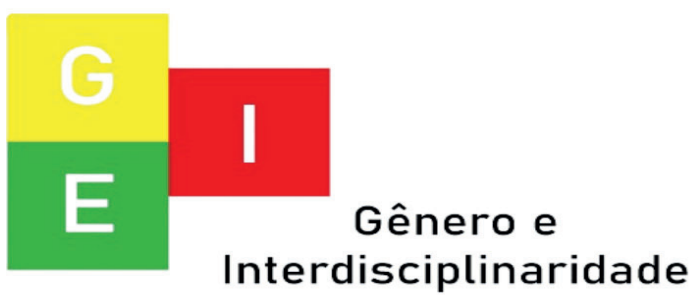


ISSN: 2675-7451

Vol. 02 - n 03 - ano 2021

Editora Acadêmica Periodicojs

seu encargo social. MELHOR INTERESSE DA

Os parentes podem

exigir uns dos ou-

CRIANÇA

tros os alimentos e os

cônjuges devem-se

A Proteção Integral à

mútua assistência. A

mulher e o esposo,

não sendo parentes

ou afins, devem-se

alimentos com fun-

damento no vínculo

conjugal. Também

os companheiros em

união estável estão

na mesma situação

atualmente. Daí de-

corre, igualmente, o

interesse público em

matéria de alimentos.

Como vemos, a obri-

gação alimentar inte-

ressa ao Estado, à so-

ciedade e à família.

(VENOSA, 2009, p.

Diante do exposto, fica

evidente que o princípio da soli-

dariedade familiar baliza a obri-

gação alimentar, especialmente a

destinada ao nascituro.

Assim, quando as ins-

tituições públicas ou privadas, autoridades, tribunais ou qual-

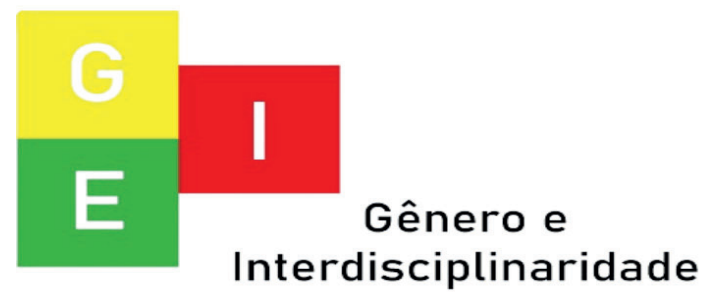


ISSN: 2675-7451

Vol. 02 - n 03 - ano 2021

Editora Acadêmica Periodicojs

quer outra entidade no momento da tomada decisões que versem acerca do nascituro, devem optar sempre por aquelas que sejam mais benéficas a este.

\section{A LEI DE ALIMENTOS GRA- VÍDICOS E SUAS INCON- GRUÊNCIAS}

A Lei $n^{\circ} 11.804 / 08$, disciplina o direito a alimentos gravídicos e a maneira como ele será executado. Vale destacar, que tal lei foi oriunda do P.L. do Senado $n^{\circ} 62$ de 2004, de autoria do falecido ex-senador Rodolpho Tourinho. Apesar da iniciativa ter sido de grande estima, o seu rascunho englobava inúmeras incongruências. Dessa maneira, foi vetada, pelo então Presidente cerca de metade dos artigos dispostos no projeto.

A citada lei supriu uma lacuna que pairava no seio jurí- dico pátrio como assevera Cícero

Goulart Assis:

A novel norma que apregoa integral proteção à mãe e ao embrião veio suprir uma triste lacuna no ordenamento jurídico brasileiro, no intuito de acabar com os dilemas sobre a fixação dos alimentos durante a gravidez, uma vez que a Lei de Alimentos ( $\left.\mathrm{n}^{\mathrm{o}} 5.478 / 68\right)$ representava um óbice à concessão dos alimentos da gestação, na medida em que exigia comprovação do vínculo de parentesco ou da obrigação alimentar. (ASSIS, 2012)

Mister observar, se o demasiado número de vetos, preencheu de fato a lacuna latente no ordenamento jurídico brasileiro, haja vista que foi desperdiçada uma oportunidade de criar um

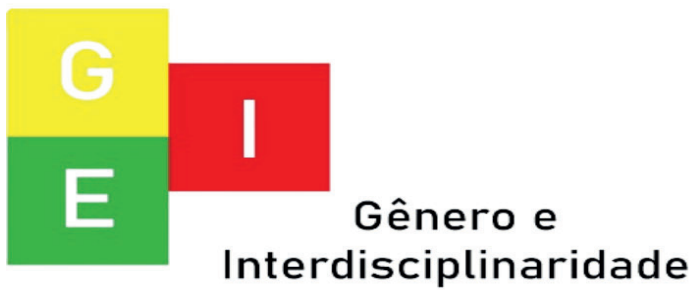


ISSN: 2675-7451

Vol. 02 - n 03 - ano 2021

Editora Acadêmica Periodicojs

diploma legal mais condizente com a causa que se propôs a defender.

Nesta senda, a dita lei traz um grande avanço, especialmente no que tange a proteção aos direitos do nascituro, todavia encontra algumas incongruências que denotam certo embate doutrinário e jurisprudencial, que serão abordadas a posteriori.

\section{OS INDÍCIOS DE PATERNI-}

\section{DADE}

Conforme dispõe o art. $6^{\circ}$ da lei de alimentos gravídicos, o magistrado irá fixá-los se tiver sido convencido da existência de indícios da paternidade, assim tais verbas irão perdurar até o nascimento da criança, observando as necessidades da parte requerente e as possibilidades da parte requerida.

Diante disso, é perceptí- vel que a título de fixação da verba, são suficientes a comprovação da gravidez e os "indícios da paternidade", não há exigência de prova cabal pré- constituída. Neste sentido, afasta a imposição de cognição plena e exauriente para que a tutela jurisdicional requerida seja deferida.

Como elucida, o Desembargador Relator, Ricardo Moreira Lins:

[...] 2. O requisito exigido para a concessão dos alimentos gravídicos, qual seja, " indícios de paternidade", nos termos do art. $6^{\circ}$ da Lei $n^{\circ}$ $11.804 / 08$, deve ser examinado, em sede de cognição sumária, sem muito rigorismo, tendo em vista a dificuldade na comprovação do alegado vínculo de parentesco já no momento do ajuizamento da ação, sob pena de não se atender à finalidade

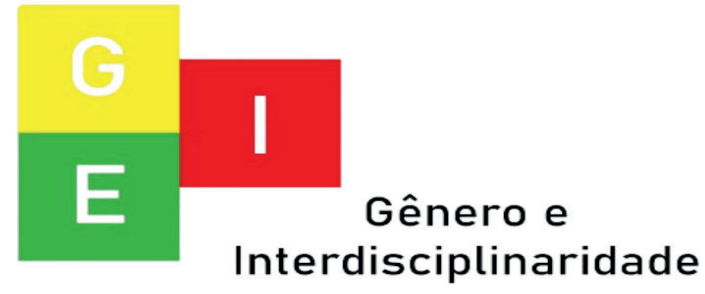


ISSN: 2675-7451

Vol. 02 - n 03 - ano 2021

Editora Acadêmica Periodicojs

da lei, que é proporcionar ao nascituro seu sadio desenvolvimento. 3. No caso, as mensagens eletrônicas trocadas entre as partes são suficientes a demonstrar plausibilidade na indicação de paternidade, sendo bastantes a indicar que as partes mantiveram relacionamento amoroso à época da concepção do nascituro, devendo ser mantida a decisão que fixou os alimentos gravídicos. GRIFO NOSSO. (TJ do RS. Agravo de Instrumento $\mathrm{n}^{\circ}: \quad 70082880873$. Relator: De. Ricardo Moreira Lins Pastl. $8^{\mathrm{a}}$ Câmara Cível. Data do julgamento: 07/11/2019).

Nesta lógica, Douglas

Phillips Freitas aduz que:

"Salvo a presunção de paternidade dos casos de lei, como imposto no art. 1.597 e seguintes, o ônus probatório é da mãe. Mesmo o pai não podendo exercer $\mathrm{o}$ pedido de Exame de DNA como matéria de defesa, cabe a genitora apresentar indícios da paternidade $^{e e}$ informada na lei através de fotos, testemunhas, cartas, e-mails, entre tantas outras provas lícitas que puder trazer aos autos, lembrando que ao contrário do que pugnam alguns, o simples pedido da genitora, por maior necessidade que há nesta delicada condição, não goza de presunção de veracidade ou há uma inversão do ônus probatório ao pai, pois este teria que fazer (já que não possui o exame pericial como meio probatório) prova

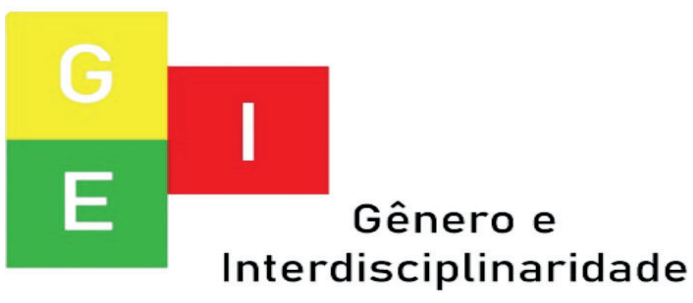


ISSN: 2675-7451

Vol. 02 - n 03 - ano 2021

Editora Acadêmica Periodicojs

negativa, o que é denota, no art. 227, que serão impossível e refutado pela jurisprudência"." (FREITAS, 2009, p. 37)

É sabido que infelizmente não há possibilidade de realização de qualquer exame pericial, em especial o exame de DNA que seria o meio de prova mais adequado para solucionar a veracidade da paternidade. Tendo em vista, que pelo menos na contemporânea conjuntura tecnológica que nos encontramos, iria expor a risco a existência do feto, o que não é admitido no cenário jurídico brasileiro que tem como como um dos princípios basilares o direito à vida, disposto no art. $5^{\circ}$, caput da $\mathrm{CF} / 88$.

Coaduna com o artigo anteriormente citado, o princípio da dignidade da pessoa humana, que concede ao nascituro o direito a alimentos, porque a $\mathrm{CF} / 88$ atendidos com extrema prioridade, o direito à vida, à saúde, entre outros. Reforçando o texto da Carta Magna, o art. $7^{\circ}$ do ECA, que assegura à criança e ao adolescente o direito à proteção à vida, à saúde, através da concretização de políticas sociais públicas que tornem possível o nascimento e o desenvolvimento sadio e harmonioso, em condições dignas de existência.

Importa salientar, que mesmo sem o exame de DNA, o suposto genitor pode demonstrar a não presunção de paternidade, que está disposta no art. $1.599^{9}$ do CC/02, como por exemplo com a apresentação de laudos médicos ou documentos que ratifiquem

9 Art. 1.599 do $\mathrm{CC} / 02$ - “A prova da impotência do cônjuge para gerar, à época da concepção, ilide a presunção de paternidade".

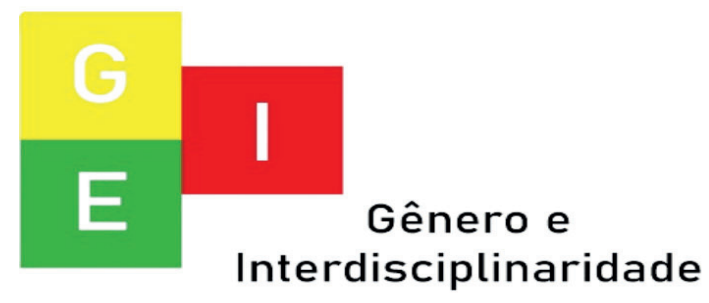


ISSN: 2675-7451

Vol. 02 - n 03 - ano 2021

Editora Acadêmica Periodicojs

uma vasectomia, impotência sexual grave ou esterilidade.

Segundo Anny Gabrielle Frez Negrão, o suposto pai ainda pode alegar:

[...] que a gestante no período da concepção manteve relações sexuais com outro homem, defesa esta que favorecia o réu, pois provocaria dúvidas ao magistrado quanto à questão de quem seria o pai biológico do nascituro, podendo tornar-se improcedente $[. .$.$] .$ Outro modo de defesa seria a alegação de que a relação sexual ocorreu em período anterior ao da concepção. (NEGRÃO, 2012, p. 20)

O posicionamento supracitado deve ser analisado de acordo com cada caso concreto. Visto que, se a genitora demonstrar indícios de paternidade, os alimentos gravídicos devem ser concedidos para a concretização do bem-estar do nascituro. E, se porventura pairar certa dúvida no magistrado, por a mãe ter praticado atividade sexual na mesma época com um ou mais homens, apresentando-se indícios para outros supostos pais, os alimentos devem ser garantidos e o valor ser dividido entre todos eles.

Já no que tange à presunção de paternidade, encon-

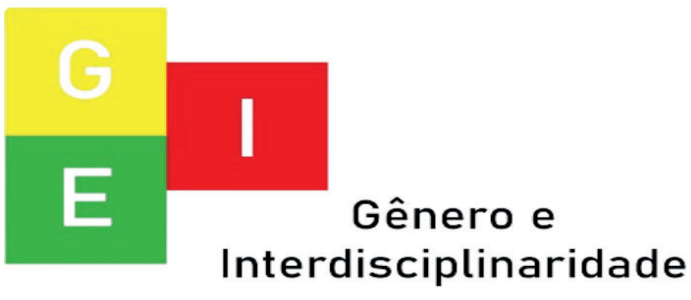


ISSN: 2675-7451

Vol. 02 - n 03 - ano 2021

Editora Acadêmica Periodicojs

tra-se nos arts. $1.597^{10}, 1.598^{11} \mathrm{e}$

10 Art. 1.597 do CC/02 -

"Presumem-se concebidos na constância do casamento os filhos: I - nascidos cento e oitenta dias, pelo menos, depois de estabelecida a convivência conjugal; II - nascidos nos trezentos dias subsequentes à dissolução da sociedade conjugal, por morte, separação judicial, nulidade e anulação do casamento; III - havidos por fecundação artificial homóloga, mesmo que falecido o marido; IV - havidos, a qualquer tempo, quando se tratar de embriões excedentários, decorrentes de concepção artificial homóloga; V - havidos por inseminação artificial heteróloga, desde que tenha prévia autorização do marido."

11 Art. 1.598 do CC/02 “Salvo prova em contrário, se, antes de decorrido o prazo previsto no inciso II do art. 1.523, a mulher contrair novas núpcias e lhe nascer algum filho, este se presume do primeiro marido, se
$1600^{12}$ do CC/02 e, não há óbice

para serem interpretadas extensivamente no tocante às hipóteses de união estável, visto que, o STJ as reconheceu no julgamento do REsp 1.194059/SP ${ }^{13}$, sob a relatoria do ministro Massami Uyeda. Entretanto, observa-se que na vigente realidade há um grande número de mulheres nascido dentro dos trezentos dias a contar da data do falecimento deste e, do segundo, se o nascimento ocorrer após esse período e já decorrido o prazo a que se refere o inciso I do art. 1597'.

12 Art. 1.600 do $\mathrm{CC} / 02$ "Não basta o adultério da mulher, ainda que confessado, para ilidir a presunção legal da paternidade"

13 STJ - REsp: 1194059 SP 2010/0085808-2. Relator: Ministro Massami Uyeda. Data de Julgamento: 06/11/2012, 3 $3^{\mathrm{a}}$ Turma. Data de Publicação: DJe 14/11/2012).

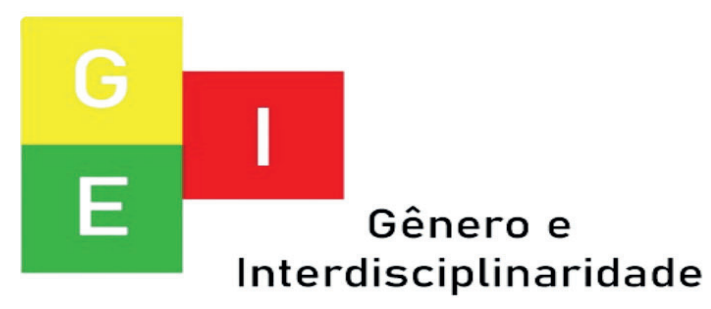


ISSN: 2675-7451

Vol. 02 - n 03 - ano 2021

Editora Acadêmica Periodicojs

solteiras que engravidam em circunstâncias bastante adversas às anteriores, por isso a importância da concessão dos alimentos gravídicos embasados nos indícios de paternidade.

Neste diapasão, o legislador pátrio diante da extrema necessidade de amparar os direitos do nascituro, flexibilizou os requisitos de teor probatório, ao afirmar que os alimentos gravídicos serão concedidos através de “indícios de paternidade". Entretanto, tal flexibilização demonstra um caráter um tanto quanto vago. Haja vista, que não há uma exemplificação do que são tais indícios, o que deixa a crivo do magistrado uma responsabilidade muito árdua.

É crível enfatizar que o juiz, consoante o art. 371 do $\mathrm{CPC} / 15$, deverá se ater às provas constantes nos autos e demonstrar na decisão os motivos que o levaram a tal convencimento.

Para posteriormente a tal análise deferir ou não os alimentos ao nascituro.

O entrave ganha holofotes quando observamos alguns julgados que não se ativeram a proteção integral da criança, disposta no art. $1^{\circ}$ do ECA, que decorre o princípio do melhor interesse da criança, a seguir:

"Contudo, no caso inexistem elementos consistentes a evidenciar o vínculo de filiação e a autorizar a fixação liminar dos alimentos gravídicos. Salienta-se que as fotos encartadas, uma carta, e as declarações unilaterais não alcançam a repercussão pretendida e são insuficientes para configurar os indícios da paternidade aventada pela recorrente. Como bem pontuou o Douto Procurador: "Verifica-se dos do-

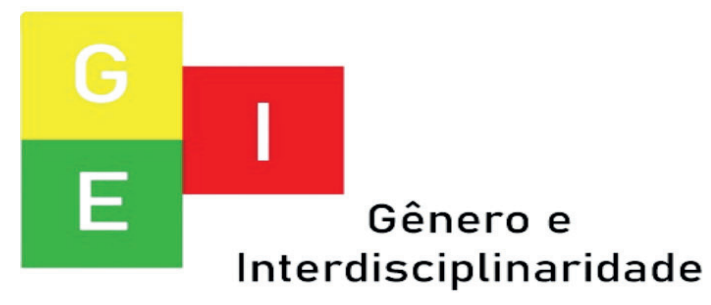


ISSN: 2675-7451

Vol. 02 - n 03 - ano 2021

Editora Acadêmica Periodicojs

cumentos que instruem a inicial que a requerente de fato está grávida, tem necessidades e havia o relacionamento amoroso entre as partes. Entretanto, não se vislumbra por ora indícios de paternidade com relação ao requerido, de modo a justificar a fixação de alimentos, no caso em apreço, nos termos do art. $6^{\circ}$ da Lei 11.804/08" (fls 71)." GRIFO NOSSO. (TJ de SP. Agravo de Instrumento $\mathrm{n}^{\circ}$ : 201304894.2020.8.26.0000. Relator: De. Donegá Morandini. $3^{\mathrm{a}}$ Câmara de Direito Privado. Data do julgamento: 09/03/2020)

A agravante sustentou a sua inconformidade com a decisão proferida pelo juízo singular que, nos autos da ação de alimentos gravídicos, indeferiu $\mathrm{o}$ pedido de alimentos provisórios. [...] Afirmou que é possível fixar algum valor a título de alimentos gravídicos, em razão da presença de fotos que comprovam o relacionamento amoroso entre as partes. Postulou o provimento do recurso, a fim de que seja, liminarmente, fixado os alimentos gravídicos provisórios, no valor de $45 \%$ do salário mínimo nacional. [...] Com efeito, em que se pese as alegações recursais, não há como decidir, em exame preliminar, sobre o pleito, sem que seja oportunizada a manifestação da parte contrária, a fim de respeitar as diretrizes formadas pelo binômio alimentar. Assim recebo o recurso apenas em seu efeito devolutivo.

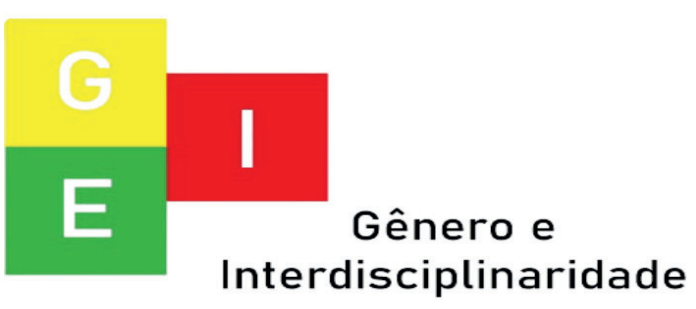


ISSN: 2675-7451

Vol. 02 - n 03 - ano 2021

Editora Acadêmica Periodicojs

Com efeito, verifica-se que a presente demanda foi ajuizada em 05.12.2018 (fls.16/29), ocasião em que a demandante encontrava-se com 20 semanas de gestação. Diante disso, tendo o agravo de instrumento sido interposto em 19.02.2019 (fl. 02), considerando o lapso temporal transcorrido desde o ajuizamento da demanda, em junho do corrente ano, requereu-se a intimação da agravante, a fim de que informasse a ocorrência do nascimento do filho, no entanto, silenciou (fls. 86 e 95). Assim, tendo em vista que a requerente, em dezembro de 2018, época do ajuizamento da demanda, encontrava-se com cerca de 05 meses de gestação, e ultrapassados mais de 08 meses desde aquela data, conclui- se que ocorreu o nascimento da criança, restando prejudicado o agravo, pela perda de objeto. GRIFO NOSSO. (TJ do RS. Agravo de instrumento $\mathrm{n}^{\circ}: \quad 70080676984$. Relator: De. José Antônio Daltoe Cezar. $8^{\mathrm{a}}$ Câmara Cível. Data do julgamento: 20/08/2019)

Diante dos julgamentos supracitados, levanta-se a seguinte indagação: até que ponto pode-se afirmar o que são indícios de paternidade suficientes? Visto que, as fotos que comprovam o relacionamento amoroso são validadas como irrisórias para concessão dos alimentos.

Dessa forma, ainda paira no nosso ordenamento o princípio do livre convencimento motivado do magistrado, que constava

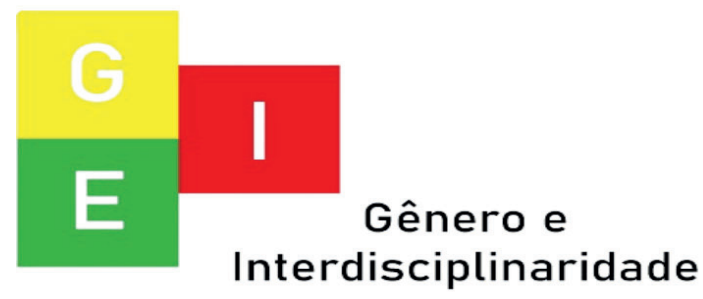


ISSN: 2675-7451

Vol. 02 - n 03 - ano 2021

Editora Acadêmica Periodicojs

no art. 131 do CPC/1973. Como elucida, Fernando da Fonseca Gajardoni da Fonseca (2015), “O fato de não mais haver no sistema uma norma expressa indicativa de ser livre o juiz para, mediante fundamentação idônea, apreciar a prova, não significa que o princípio secular do direito brasileiro deixou de existir."

Resta cristalino, que o juiz tem o crivo de valorar a prova, visto que, no caso sob a relatoria do desembargador Claudio Godoy, observa-se que ele pôs a venda para se ater aos indícios de paternidade prejudicando e cerceando os direitos do nascituro. O julgador José Daltoe, por sua vez, apesar de reconhecer o lastro probatório anexado aos autos pela genitora, por conta da morosidade da justiça não conseguiu alcançar o seu próprio desiderato, tendo em vista a perda do objeto, pois os alimentos gravídicos são considerados irretroativos.

Nota-se que de fato é penoso ao juiz, deferir ou não os alimentos gravídicos somente pelos indícios de paternidade, pois ele esbarra nas características da irrepetibilidade e da irretroatividade dos alimentos. Tendo em vista, que diante da literalidade das características, se houver a concessão e o pai não for o verdadeiro, podendo a genitora ter agido de má-fé ou não, este não poderá ser ressarcido e, se não ocorrer o deferimento por o magistrado entender que há "insuficiência de indícios", em hipótese do suposto genitor ser o biológico, os alimentos gravídicos não podem ser prestados de forma retroativa.

Importa salientar que, conforme Lafayette Rodrigues Pereira (1956, p.337), “Os alimentos são destinados a remediar necessidades cuja satisfação

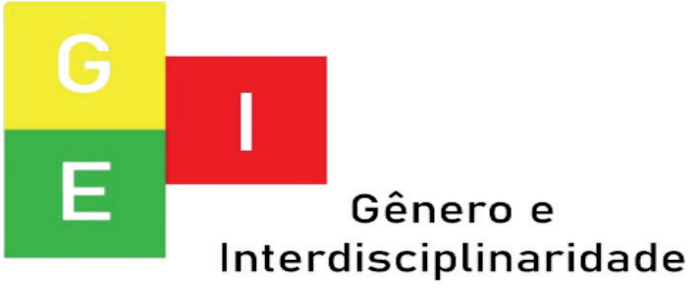


ISSN: 2675-7451

Vol. 02 - n 03 - ano 2021

Editora Acadêmica Periodicojs

não pode ser remediada nem declinada". Assim, se há indícios de paternidade o judiciário não pode se recusar a conceder os alimentos gravídicos.

Segue-se o posicionamento do desembargador Rui Portanova, nas razões expostas em decisão monocrática, analisa a concessão dos alimentos gravídicos sob o prisma do risco:

Risco. Para além dos termos da lei, não se pode perder de vista que está na base do novel instituto, um certo grau de risco que o juiz deve correr. Não se vá exigir tanta prova que o instituto fique inviabilizado. $\mathrm{O}$ risco de erro judicial, bem sopesado, deve elevar em conta um juízo de proporcionalidade. Com efeito, menor será o dano ao se punir, num eventual erro, o agravado com o ônus de uma obrigação que não é sua. Por outro lado, maior será o dano se o futuro mostrar que o agravado é o pai. GRIFO NOSSO. (TJ do RS. Agravo de instrumento $\mathrm{n}^{\mathrm{o}}$ : 70029315488. Relator: De. Rui Portanova. $8^{\circ}$ Câmara Cível. Data do julgamento: 31/03/2009)

Logo, fica evidente a dificuldade de analisar a concessão dos alimentos ao nascituro com base apenas em indícios, esses deveriam ao menos serem exemplificados em lei. Mas, não há outra forma para tanto, pois como o que de fato importa é assegurar os direitos do nascituro, os indícios precisam bastar para o magistrado. E, caso depois do nascimento da criança, for constatado que o/s suposto/s pai/s não é/são $\mathrm{o} / \mathrm{s}$ verdadeiro/s, que houve erro do judiciário, deve-se adentrar no

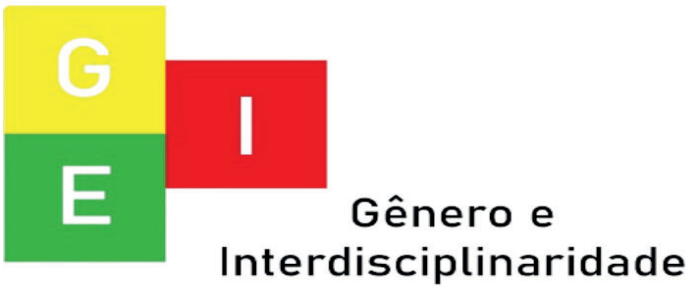


ISSN: 2675-7451

Vol. 02 - n 03 - ano 2021

Editora Acadêmica Periodicojs

campo polêmico da responsabilidade civil no âmbito dos alimentos do nascituro para resolver a questão.

\section{A LEGITIMIDADE ATIVA E} PASSIVA

No que tange à legitimidade ad causam ativa de propor alimentos gravídicos, a lei expressa que o titular é a genitora. Esse posicionamento é abarcado por vários doutrinadores, que observam a literalidade do artigo primeiro $^{14}$ - que aduz: "o direito de alimentos da mulher gestante" - logo, nessa primeira corrente doutrinária traz que nas entrelinhas a genitora é tratada como a legítima para propor a ação de

14 Lei $\mathrm{n}^{\mathrm{o}}$ 11.804, de 2008, art. $1^{\circ}$ - "Esta Lei disciplina o direito de alimentos da mulher gestante e a forma como será exercido." alimentos gravídicos, como assevera Delfino:

"Se o critério se cingir a uma interpretação literal, tal titularidade caberia apenas à gestante. Afinal, o art. $1^{\circ}$ da Lei n. 11.804/2008 estabelece que ela disciplina o direito de alimentos da mulher gestante. Também a mesma impressão se colhe ao se ler o art. $6^{\circ}$, parágrafo único: "Após o nascimento com vida, os alimentos gravídicos ficam convertidos em pensão alimentícia em favor do menor até que uma das partes solicite a sua revisão." À gestante caberia a legitimidade de ajuizar demanda para a tutela de alimentos gravídicos; ao nascituro cumpriria o papel meramente passivo de aguardar eventual tutela jurisdicional que o

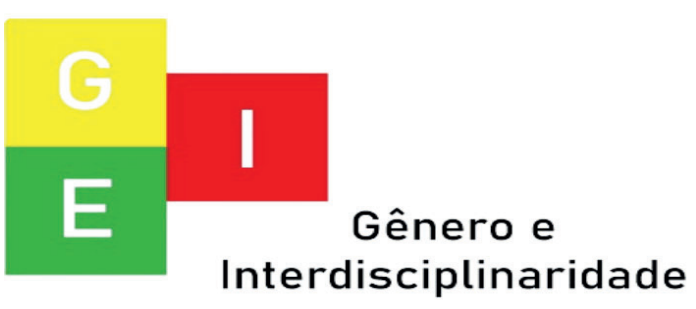


ISSN: 2675-7451

Vol. 02 - n 03 - ano 2021

Editora Acadêmica Periodicojs

beneficie." (DELFI-

NO, 2009, p.196)

Consoante Maria Berenice Dias (2016, p. 970), “A legitimidade ativa para a ação é da gestante, que promove a ação em nome próprio". No mesmo sentido, declinou Carlos Roberto Gonçalves (2017, p. 751), “[...] legitimidade ativa à própria gestante para a propositura da ação de alimentos [...]".

Destarte, a genitora seria uma beneficiária indireta $\mathrm{e}$ exerceria uma espécie de legitimidade extraordinária, porque atua em nome próprio, defendendo direito alheio, sendo parte principal no processo, isto é, não é representante do titular do direito controvertido.

Seguindo a citada literalidade da lei, o STJ julgou o seguinte:
Os alimentos gravídicos, previstos na Lei n. 11.804/2008, visam auxiliar a mulher gestante nas despesas decorrentes da gravidez, da concepção ao parto, sendo, pois, a gestante a beneficiária direta dos alimentos gravídicos, ficando, por via de consequência, resguardados os direitos do próprio nascituro. GRIFO NOSSO. (Recurso Especial sob o $\mathrm{n}^{\mathrm{o}}$ : 1.629.423SP. Relator: Min. Marco Aurélio Bellizze. Data do julgamento: 06/06/2017).

Maria Isabel Ferreira

Marques, aduz que:

[...] cabe à gestante ingressar com a ação, pois é ela a detentora do direito a alimentos. E por ser essa a perspectiva mais garantidora da dignidade da pessoa

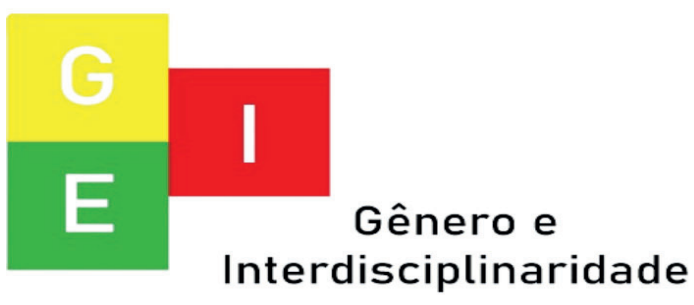


ISSN: 2675-7451

Vol. 02 - n 03 - ano 2021

Editora Acadêmica Periodicojs

humana, é a que deve prevalecer. Reconhecê-la assim vai ao encontro da almejada proteção à maternidade e, consequentemente, do nascimento digno da criança. (MARQUES, 2019, p. 307)

No caso de conversão de titularidade após o nascimento da criança com vida, passando de alimentos gravídicos à qualidade de pensão alimentícia em favor da criança, não há divergência doutrinária, pois fica evidente que a legitimidade ativa é do nascituro, representado pela genitora. Não há impedimento para que o Ministério Público figure no polo ativo da ação de alimentos gravídicos quando a mãe for menor ou incapaz e não possuir curador.

Entretanto, no campo da legitimidade ativa na ação de alimentos há quem entenda que os alimentos gravídicos são nada menos que, alimentos do nascituro. Logo, para a segunda corrente a dita titularidade é do nascituro. Sob a ótica de que possuem embasamento nos direitos do nascituro, essa segunda corrente aduz que o real autor da ação de alimentos gravídicos deveria ser o nascituro. Haja vista que o artigo $2^{\circ}$, do $\mathrm{CC} / 02$, já amparou os seus direitos (somente a teor de conhecimento: o art. 1.609, parágrafo único, que permite o reconhecimento de paternidade anteriormente ao nascimento do filho).

Vale destacar, que os alimentos têm como destinatário final o nascituro, apesar da mãe ser a receptora primária, pois é essencial a garantia da sua saúde para que a vida que está por vir permaneça resguardada. Assim,

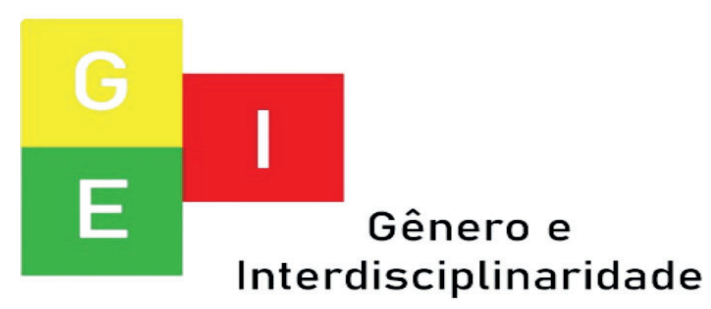


ISSN: 2675-7451

Vol. 02 - n 03 - ano 2021

Editora Acadêmica Periodicojs

os alimentos são destinados ao nascituro e, somente auferidos pela genitora.

Silmara Juny Chinellato afirma que o polo ativo deve pertencer ao nascituro:

A Lei n. 11.804, de 05.11.2008, que trata dos impropriamente denominados "alimentos gravídicos" -desnecessário e inaceitável neologismo, pois alimentos são fixados para uma pessoa e não para um estado biológico da mulher -embora com louvável intuito de proteção da vida pré-natal, desconhece que o titular do direito a alimentos é o nascituro e não a mãe, partindo de premissa errada, o que repercute no teor da lei. (CHINELLATO, 2017, p. 39)

Flávio Tartuce (2016), concorda com o posicionamento anterior, pois estaria em consonância com a evolução doutrinária brasileira, haja vista que denota o reconhecimento dos direitos do nascituro, especialmente os de natureza existencial, embasados na sua personalidade. Ainda para o doutrinador, essa lei deveria ter outro nome, como, por exemplo, "lei dos alimentos do nascituro".

No mesmo sentido, afirma o Desembargador Relator Alan Sebastião Sena Conceição do TJ de GO, 5 a Câmara Cível, em AC 0297998-59.2017.8.09.0006, que foi julgado em 22/03/2019, “[...] alimentos gravídicos cuja titularidade é, na verdade do nascituro e não da mãe [...]".

Cristiano Chaves de Farias/Nelson Rosenvald também defendem que o polo ativo é do nascituro, representado pela mãe: Apesar de alguma controvérsia doutrinária, parece-nos certo que, interpre-

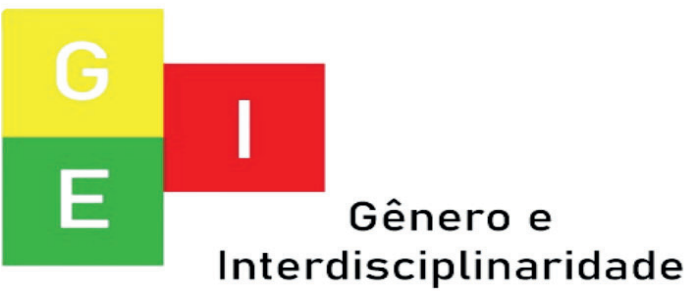


ISSN: 2675-7451

Vol. 02 - n 03 - ano 2021

Editora Acadêmica Periodicojs

tando o que consta do art. $1^{\circ}$ do aludido Diploma Legal, a legitimidade para ajuizar a ação de alimentos gravídicos é do nascituro, representado pela gestante. Isto porque $o$ art. $6^{\circ}$ da citada Lei é de clareza solar ao afirmar que, fixados os alimentos gravídicos e sobrevindo o nascimento sem impugnação da paternidade, eles serão convertidos em pensão alimentícia em favor da criança. Ora, se os alimentos gravídicos se convertem em pensão alimentícia em favor do infante, logicamente é porque foram fixados em seu favor. (CHAVES DE FARIAS; ROSENVALD, 2011, p. 287)

Vale destacar, que alguns doutrinadores, como a Maria Berenice Dias (2016, p.
971), têm admitido inclusive litisconsórcio passivo de natureza eventual quando a genitora não puder indicar somente um suposto ente paterno, por exemplo em caso de violência sexual realizada por dois ou mais homens. Até ser identificado quem é o pai, os alimentos devem ser pagos por todos os supostos genitores, de maneira solidária.

Outro ponto importante é que o direito aos alimentos, como elucida Yussef Cahali (1998), é um direito personalíssimo, por ser inerente ao próprio necessitado, levando-se em consideração a pessoa deste ao amparar a sua subsistência; na medida em que a obrigação não é transmissível, porque está embasada no laço de parentesco que une um indivíduo ao outro, o credor ao devedor de alimentos.

Não se transmite a titu-

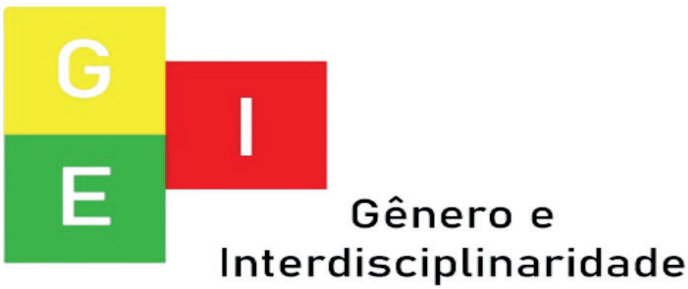


ISSN: 2675-7451

Vol. 02 - n 03 - ano 2021

Editora Acadêmica Periodicojs

laridade da obrigação de prestar alimentos, seja por negócio jurídico, seja por fato jurídico, o que não é para ser confundido com a obrigação subsidiária dos demais parentes que são chamados a prestar alimentos, na ausência ou impossibilidade dos mais próximos, nem com a responsabilidade sucessória pelas prestações alimentícias vencidas até a data do óbito do alimentante, pelas quais respondem os sucessores nos limites de força da herança.

Tal discussão é de extrema importância, já que tem corolário na definição do polo passivo, porque, para os que defendem que a legitimidade ativa é do nascituro, a obrigação da prestação de alimentos, caso o suposto genitor seja morto ou não tenha poder aquisitivo, pode englobar os avós, conforme a súmula $\mathrm{n}^{\circ}$ 596 do $\mathrm{STJ}^{15}$ e, pode alcançar os

15 Súmula 596 do STJ - “A demais familiares conforme os arts. $1694^{16}, 1.696^{17}$ e $1.698^{18}$ do

obrigação alimentar dos avós tem natureza complementar e subsidiária, somente se configurando no caso de impossibilidade total ou parcial de seu cumprimento pelos pais." (Julgada em 08/11/2017, DJe 20/11/2017).

16 Art. 1.694 do CC/02 "Podem os parentes, os cônjuges ou companheiros pedir uns aos outros os alimentos de que necessitem para viver de modo compatível com a sua condição social, inclusive para atender às necessidades de sua educação". 17 Art. 1696 do CC/02 - "O direito à prestação de alimentos é recíproco entre pais e filhos, e extensivo a todos os ascendentes, recaindo a obrigação nos mais próximos em grau, uns em falta de outros".

18 Art. 1.698 do CC/02 - "Se o parente, que deve alimentos em primeiro lugar, não estiver em condições de suportar totalmen-

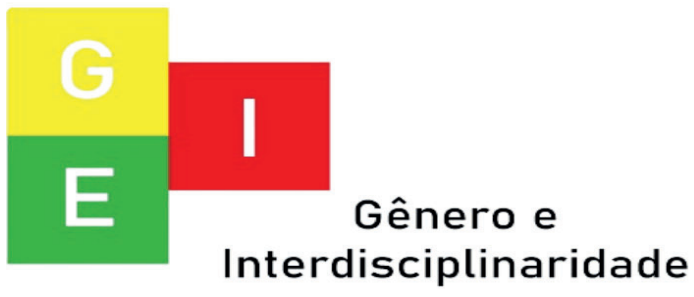


ISSN: 2675-7451

Vol. 02 - n 03 - ano 2021

Editora Acadêmica Periodicojs

CC/02, alicerçado também no princípio da solidariedade familiar e da dignidade da pessoa humana.

Como bem exprime o Desembargador Relator Luiz Felipe Schuch, do TJSC:

"Delineada a controvérsia, conquanto não se trate, no caso, de ação de alimentos, uma vez que as despesas aqui tratadas são anteriores ao reconhecimento judicial da paternidade, não se pode perder de vista que "podem os parentes, os cônjuges ou companheiros pedir uns aos outros alimentos [...]

te o encargo, serão chamados a concorrer os de grau imediato; sendo várias as pessoas obrigadas a prestar alimentos, todas devem concorrer na proporção dos respectivos recursos, e, intentada ação contra uma delas, poderão as demais ser chamadas a integrar a lide."
Ainda, uma vez demonstrada a incapacidade financeira do suposto pai, há possibilidade de o encargo ser transferido aos supostos avós [...]". GRIFO NOSSO. (TJ de SC. Apelação Cível n: 000560960.2013.8.24.0067. Relator: De. Luiz Felipe Schuch. Câmara Especial Regional de Chapecó. Data do julgamento: 11/12/2017).

O problema é que, segundo os doutrinadores que trazem a legitimidade ativa sendo da mãe, o polo passivo só abarca o pai, sob o argumento de que para alcançar os demais familiares há uma necessidade de comprovação de parentesco. Assim sendo, como a realização de exame de DNA pode prejudicar o feto, torna impossível a constatação do vínculo.

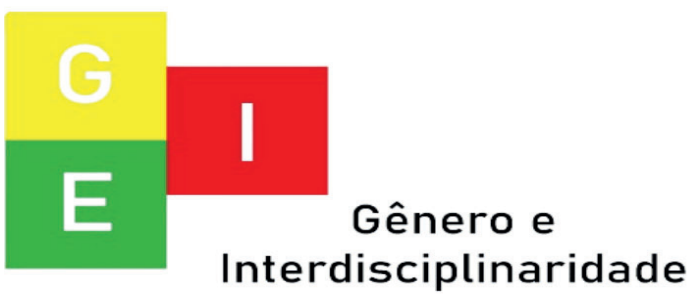


ISSN: 2675-7451

Vol. 02 - n 03 - ano 2021

Editora Acadêmica Periodicojs

Entretanto, apesar de te na lei que a legitimidade ativa Maria Berenice Dias (2016, p. pertence a mãe?

973) entender que a legitimida-

Entende-se que de fato

de pertence à mãe, ela acredita seria um retrocesso, tendo em que há possibilidade de se exigir vista que ao conferir a titularialimentos gravídicos avoengos dade a mulher grávida, o cunho quando o suposto pai não puder passivo da ação será direcionado arcar com as despesas.

ao suposto genitor, sem poder se

Cumpre trazer à baila, que já ocorreu decisão precursora, no decurso da tramitação da apelação cível no 193.648-1, julgada em 14/09/1993, pela $1^{a}$ Câmara do TJ de SP, em que se determinou a legitimidade ad causam ao nascituro, representado pela genitora, visto que ele possuiria expectativa de direito resguardada.

Tal decisão é bem anterior à vigência da lei de alimentos gravídicos, mas já demonstrava eloquente saber ao conceder a legitimidade ativa ao nascituro. Dessa forma, seria ou não um retrocesso, dispor expressamenestender aos seus parentes. Assim, diante do princípio do melhor interesse da criança já mencionado no presente trabalho, optamos pela legitimidade ativa ser do nascituro, representado por sua genitora e o polo passivo ser do suposto pai abarcando seus familiares, caso ele seja falecido ou não tenha recursos financeiros suficientes para arcar com os alimentos na sua totalidade.

Já no que tange à legitimidade passiva poder abarcar mais de um suposto pai, através do litisconsórcio, declina-se por ser plenamente possível quando a mãe não tiver como indicar

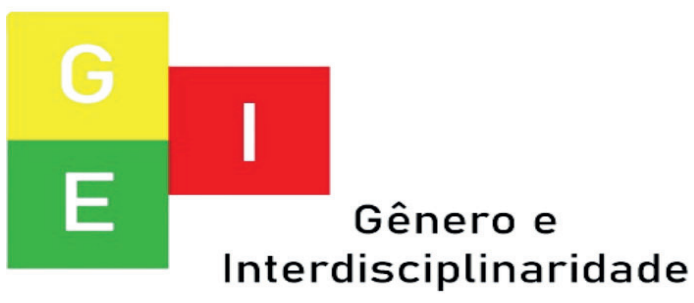


ISSN: 2675-7451

Vol. 02 - n 03 - ano 2021

Editora Acadêmica Periodicojs

apenas um possível genitor, especialmente com base no princípio da paternidade responsável. Haja vista, que não seria justo a genitora arcar sozinha com os alimentos gravídicos.

Portanto, foi visto que o debate acerca da legitimidade é pungente. Dessa forma, o magistrado fica na berlinda em optar pela literalidade da lei que rege os alimentos gravídicos ou utilizar o bom senso em se valer da solidariedade familiar e da paternidade responsável para amenizar o conflito.

\section{O TERMO INICIAL}

Atinente ao termo inicial para a prestação de alimentos gravídicos, há grande divergência doutrinária e jurisprudencial. Sendo que, colidem com três correntes sobre essa questão: a primeira de que os alimentos graví- dicos obrigam o genitor a partir da citação, a segunda com base no ajuizamento da ação e, a terceira desde a concepção.

Frisa-se, que o PL sob o n. ${ }^{\circ} 7.376 / 2006$ tratava acerca dos alimentos gravídicos e, em seu art. $9^{\circ}$, afirmava que o dever de prestar alimentos pelo suposto pai era desde a data da sua citação. Todavia, esse artigo foi vetado pelo Presidente da República da época em Mensagem de Veto n. $^{\circ} 853$, de 5 de novembro de 2008, a seguir transcrita:

$\mathrm{O}$ art. 9o prevê que os alimentos serão devidos desde a data da citação do réu. Ocorre que a prática judiciária revela que o ato citatório nem sempre pode ser realizado com a velocidade que se espera e nem mesmo com a urgência que o pedido de alimentos requer. Determinar que os alimentos graví-

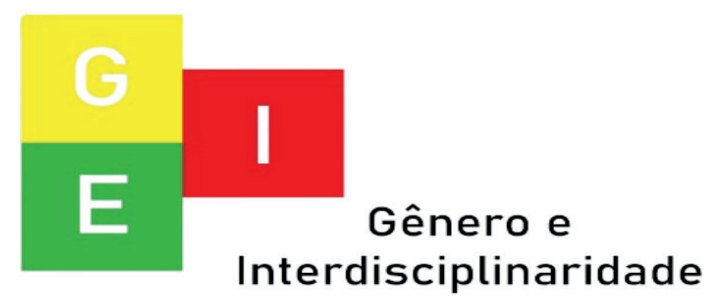


ISSN: 2675-7451

Vol. 02 - n 03 - ano 2021

Editora Acadêmica Periodicojs

dicos sejam devidos

a partir da citação

do réu é condená-lo, desde já, à não-existência, uma vez que a demora pode ser causada pelo próprio réu, por meio de manobras que visam impedir o ato citatório. Dessa forma, o auxílio financeiro devido à gestante teria início no final da gravidez, ou até mesmo após o nascimento da criança, o que tornaria o dispositivo carente de efetividade. GRIFO NOSSO. (BRASIL, 2008)

Entretanto, citando Denis Donoso, bem como julgado do TJ do Paraná, há persistência com o posicionamento citatório, respectivamente:

[...] sustento que os alimentos gravídicos são devidos desde a citação do devedor. A uma, porque só a citação que consti-

tui em mora [...]; a duas, porque a LAG se aplicam supletivamente as disposições da Lei de Alimentos (conforme previsto no art. 11 da LAG), e esta prevê que os alimentos fixados retroagem à data da citação (art. 13, § $2^{\circ}$ ). A tendência que aponto se confirma pelo que se lê na Súmula $n^{\circ} 227$ do STJ, pela qual, julgada procedente a investigação de paternidade, os alimentos são devidos a partir da citação. Não vejo motivos para compreender os alimentos gravídicos de forma distinta. GRIFO NOSSO. (DONOSO, 2009, p. 107)

VISTOS, estes autos de Agravo de Instrumento sob $\mathrm{n}^{\circ}$. 655.776-6, da Vara Única da Comarca de Ribeirão Claro, em

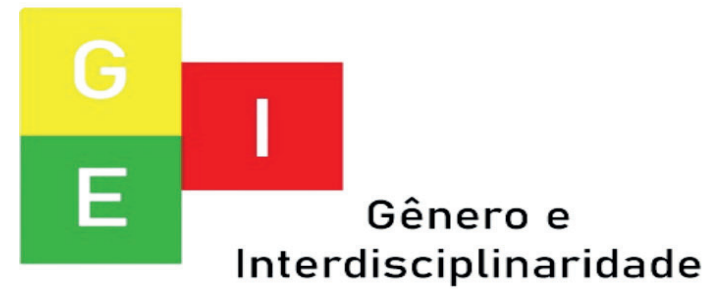


ISSN: 2675-7451

Vol. 02 - n 03 - ano 2021

Editora Acadêmica Periodicojs

que é agravante $\mathrm{T}$.

R. M. e agravada C.

C. M. M.. 1. Trata-se

de agravo de instrumento interposto por T. R. M., em face de decisão proferida nos autos de ação de separação judicial litigiosa $\mathrm{c} / \mathrm{c}$ liminar para administrar a empresa e alimentos gravídicos, autos $\mathrm{n}^{\mathrm{o}}$ 007/2010, movida pelo ora agravada contra o agravante, que deferiu o pedido liminar de alimentos gravídicos provisórios, arbitrados em montante equivalente a um salário mínimo nacional vigente, ou seja, R\$ 510,00 (quinhentos e dez reais), devidos mensalmente pelo requerido a partir da citação,[...]. GRIFO NOSSO. (TJ do PR. Agravo de instrumento $\mathrm{n}^{\circ}$ : 655.776-6. Relator:

De. Costa Barros. Vara Única da Comarca de Ribeirão Claro. Data do julgamento: 17/03/2010)

Já para Arnaldo Rizzardo, acerca do ajuizamento da ação, in verbis:

Colidia com o artigo $9^{\circ}$ também com a redação do art. $4^{\circ}$ da Lei de Alimentos (Lei $\mathrm{n}^{\mathrm{o}}$ 5.478, de 25.07.1968), que determina ao juiz, quando despachar a inicial, fixar, desde logo, os alimentos provisórios. Dessa forma, a Lei $\mathrm{n}^{\circ}$ 11.804 adotou a posição consagrada na doutrina e na jurisprudência, e também expressa legalmente, ou seja, o juiz deve fixar os alimentos ao despachar a petição inicial. GRIFO NOSSO. (RIZZARDO, 2019, p. 1197)

De forma diametral-

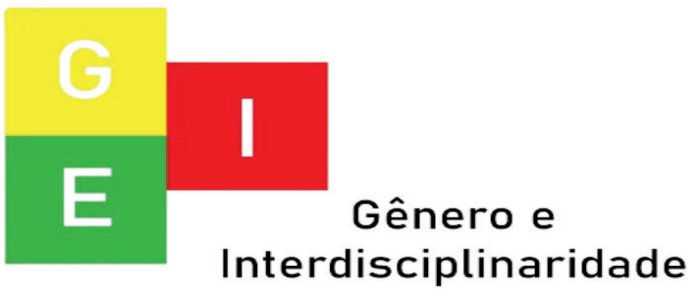


ISSN: 2675-7451

Vol. 02 - n 03 - ano 2021

Editora Acadêmica Periodicojs

mente oposta às posições anteriores, Rolf Madaleno (2019, p.77) assevera, "Os alimentos gravídicos são devidos a partir da concepção e não após a citação do réu, como chegou a ensaiar o texto vigente que neste ponto mereceu veto presidencial [...]”. Segue o mesmo posicionamento, Maria Berenice Dias (2016, p. 970), “Em face do seu caráter indenizatório, melhor é a tese de que são devidos a partir da concepção"

O Desembargador Relator Raduan Miguel Filho do TJ de RO, 1ª Câmara Cível, em apelação cível $n^{\circ}: 00077056520118220102$, que foi julgada em 22/10/2013, traz que, "O auxílio financeiro devido à gestante deve ter início a partir da concepção, dada a natureza emergencial dos alimentos gravídicos tanto quanto porque elimina os óbices processuais e a má-fé do devedor acaso forem fixados a partir da citação”.

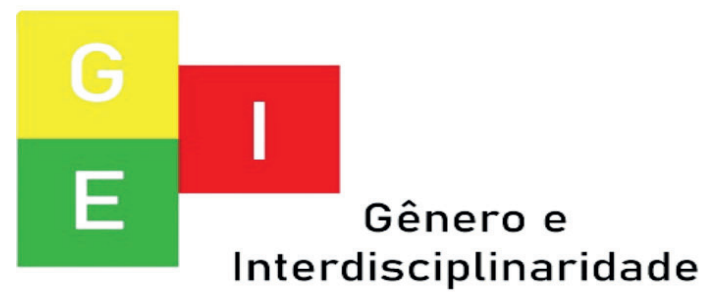

Nesta senda, numa interpretação mais sistemática, o art. $2^{\circ}$, parágrafo único da própria lei de alimentos gravídicos, traz que as despesas gestacionais devem ser compartilhadas com o suposto pai da concepção ao parto. Também, tem fulcro o termo inicial a partir da concepção, no art. $4^{\circ}$ do Pacto de São José e no art. $2^{\circ}$ do $\mathrm{CC} / 02$.

Diante de todo o exposto, a melhor vertente é a que segue o direcionamento de que os alimentos destinados ao ente que se encontra no útero materno serão devidos desde a concepção.

\section{A (IR)RETROATIVIDADE} DOS ALIMENTOS GRAVÍDICOS DIANTE DA NÃO CONCESSÃO E POSTERIOR COMPROVAÇÃO DE PATERNIDADE

Os alimentos gravídicos 
ISSN: 2675-7451

Vol. 02 - n 03 - ano 2021

Editora Acadêmica Periodicojs

seguem muitas características

dos alimentos, em especial a ir-

retroatividade. Entretanto, com o

indeferimento dos alimentos ao

nascituro e posterior comprova-

ção da paternidade vem à tona

a discussão da (im)possibilidade

dos alimentos gravídicos retroa-

tivos.

Acerca da irretroativi-

dade dos alimentos, aduz Arnal-

do Rizzardo:

“[...] não se pode obrigar ao pagamento de alimentos relativamente a período anterior ao ingresso da ação. Mesmo que o necessitado tenha contraído dívidas para viver, não é permitido que retroaja o período a determinada época, embora o entendimento contrário de San Tiago Dantas: "Se não contraiu dívidas para viver, os alimentos pretéritos não são de- vidos, pois inpraete-

ritum non vivitur, diz

um brocardo, e, evi-

dentemente, como a

prestação alimentar é

devida para que o ali-

mentário viva, se ele

já viveu, a prestação

é inútil. Não há mo-

tivo algum para que

se obrigue à prestação, se aí o alimen-

tário, bem ou mal, já sobreviveu. [...] Se, porém, só conseguiu viver graças a dívidas que contraiu com terceiros, então pode pedir os alimentos pretéritos para pagar essas dívidas. Ele não precisa pedir os alimentos pretéritos; aquele mesmo que lhe fez o empréstimo pode reclamar

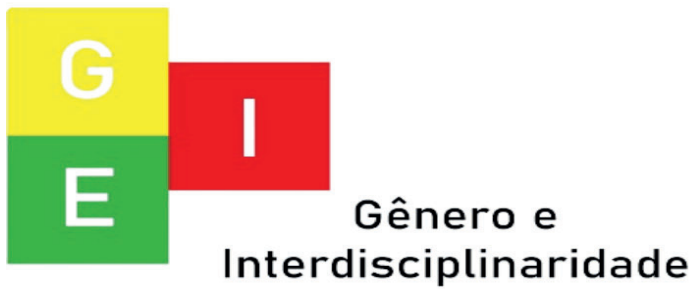


ISSN: 2675-7451

Vol. 02 - n 03 - ano 2021

Editora Acadêmica Periodicojs

ao alimentante o re-

embolso na forma da

hipótese anterior."”

(RIZZARDO，2019,

p. $1145-1146$ )

Crível observar os po-

sicionamentos jurisprudenciais a

seguir:

Vencido o relator que

votou pela concessão

dos alimentos gra-

vídicos retroativos à

data da citação; por

maioria restou inde-

ferido o pedido de

fixação de alimentos

gravídicos. [...] Po-

der-se-ia pensar na

hipótese de os ali-

mentos retroagir, no

presente caso, à data

do indeferimento da

antecipação de tu-

tela dos alimentos

gravídicos, isto é, a

$13 / 10 / 2015$ e não à

data de citação do

alimentante, ocorrida

em 04/12/2015. Con-

tudo, o apelante pede

a retroação à data da

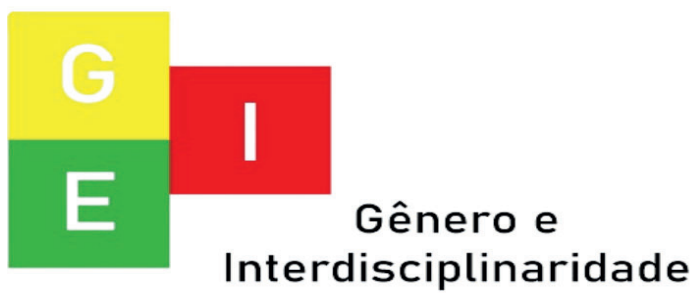

citação (04/12/2015).

Logo, sob pena de ir

além do pedido, não

se pode retroagir à

data anterior àquela

que foi pedida. [...]

Ademais, há enten-

dimento consolida-

do do STJ acerca da

possibilidade de fixa-

ção de alimentos gra-

vídicos retroativos.

Demonstra a Súmula

277, apresentada no

apelo do alimentado:

Julgada procedente a

investigação de pa-

ternidade, os alimen-

tos são devidos a par-

tir da citação. GRIFO

NOSSO. (TJ do RS.

Apelação Cível $\mathrm{n}^{\circ}$ :

70081660391. Rela-

tor: De. Rui Portano-

va. $8^{\mathrm{a}}$ Câmara Cível.

Data do julgamento:

26/09/2019).

Considerando a certeza da paternidade, também é certo que o apelado deveria ter contribuído com alimentos gravídicos, para contribuir com 
ISSN: 2675-7451

Vol. 02 - n 03 - ano 2021

Editora Acadêmica Periodicojs

as despesas presua concessão do mesmo. Entre-

midas de gestação. Caso em que se defere a condenação retroativa de alimentos gravídicos, compreendida no período entre a citação do réu até o nascimento do filho. GRIFO NOSSO. (TJ do RS. Apelação Cível $\mathrm{n}^{\circ}$ : 700077253714. Relatora: De. Liselena Schifino Robles Ribeiro. $7^{\text {a }}$ Câmara Cível. Data do julgamento: 30/05/2018).

Diante da análise dos julgados supracitados, pode-se suspender que no palco dos tribunais paira uma grande divergência acerca da concessão ou não dos alimentos gravídicos retroativos.

Destarte, observa-se sabiamente que já ocorre a relativização do princípio da irretroatividade dos alimentos para

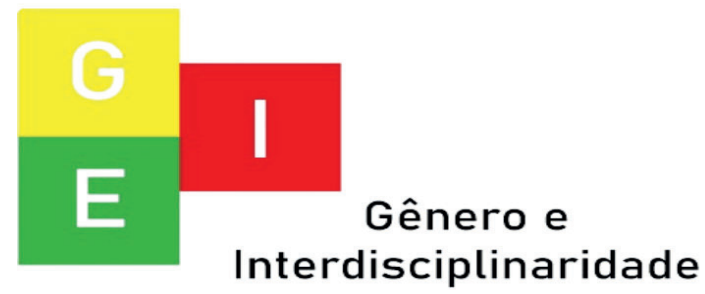

que os alimentos gravídicos devem retroagir com termo inicial a partir da concepção diante da não concessão a priori e posterior comprovação de paternidade.

A (IM)POSSIBILIDADE DE EXIGÊNCIA DOS DANOS 
ISSN: 2675-7451

Vol. 02 - n 03 - ano 2021

Editora Acadêmica Periodicojs

MATERIAIS E/OU MORAIS PELO "NÃO PAI"

Os alimentos gravídicos são concedidos com base em indícios de paternidade e o suposto pai pode até ter a sua prisão civil ${ }^{19}$ decretada se injustificadamente não realizar o devido pagamento. Entretanto, o entrave surge no tocante a (im)possibilidade de exigência de danos materiais e/ou morais quando o suposto genitor que arcou com todas as despesas gestacionais, após o nascimento com vida da criança, verificar que o exame pericial de paternidade deu negativo.

Antes de adentrar na problemática, mister salientar 19 V Jornada de Direito Civil do Conselho da Justiça Federal no Enunciado ${ }^{\circ} 522$ - Cabe prisão civil do devedor nos alimentos gravídicos estabelecidos com base na Lei n. 11.804/2008, inclusive deferidos em qualquer caso de tutela de urgência". que o art. $5^{\circ}, \mathrm{XXXV}$, da $\mathrm{CF} / 88$, dispõe que "a lei não excluirá da apreciação do poder judiciário lesão ou ameaça de direito" e, que os pleitos de indenização por dano moral e material estão alicerçados nos arts. $186^{20}, 187^{21}$, $927^{22}$ do CC/02 e também de for-

20 Art. 186 do CC/02 “Aquele que, por ação ou omissão voluntária, negligência ou imprudência, violar direito e causar dano a outrem, ainda que exclusivamente moral, comete ato ilícito."

21 Art. 187 do CC/02 “Também comete ato ilícito o titular de um direito que, ao exercê-lo, excede manifestamente os limites impostos pelo seu fim econômico ou social, pela boa-fé ou pelos bons costumes."

22 Art. 927 do CC/02 “Aquele que, por ato ilícito (arts. 186 e 187), causar dano a outrem, fica obrigado a repará- lo. Parágrafo único. Haverá obriga-

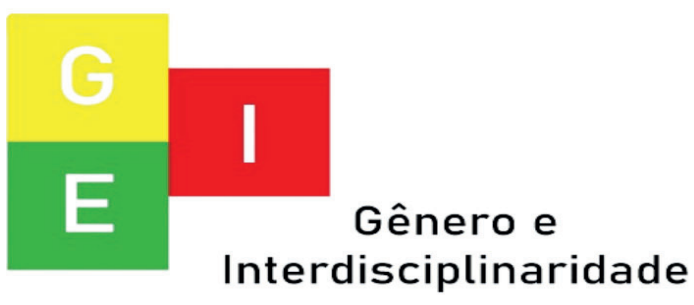


ISSN: 2675-7451

Vol. 02 - n 03 - ano 2021

Editora Acadêmica Periodicojs

ma expressa na $\mathrm{CF} / 88$ em seu art. $5^{023}$, V e X.

O PL nº. 7.376/2006, no $\underline{\text { seu art. } 10^{\circ} \text { trazia que em caso }}$ ção de reparar o dano, independentemente de culpa, nos casos especificados em lei, ou quando a atividade normalmente desenvolvida pelo autor do dano implicar, por sua natureza, risco para os direitos de outrem."

23 Art. $5^{\circ}$ da CF/88 - “Todos são iguais perante a lei, sem distinção de qualquer natureza, garantindo-se aos brasileiros e aos estrangeiros residentes no País a inviolabilidade do direito à vida, à liberdade, à igualdade, à segurança e à propriedade, nos termos seguintes: [...] V - é assegurado o direito de resposta, proporcional ao agravo, além da indenização por dano material, moral ou à imagem; [...] X - são invioláveis a intimidade, a vida privada, a honra e a imagem das pessoas, assegurado o direito a indenização pelo dano material ou moral decorrente de sua violação;" negativo do exame de DNA, a genitora iria ter a responsabilidade objetiva, pelos danos materiais e morais ocasionados ao réu, entretanto, o Presidente da República da época vetou o citado artigo sob o argumento:

Trata-se de norma intimidadora, pois cria hipótese de responsabilidade objetiva pelo simples fato de se ingressar em juízo e não obter êxito. $\mathrm{O}$ dispositivo pressupõe que o simples exercício do direito de ação pode causar dano a terceiros, impondo o autor o dever de indenizar, independentemente da existência de culpa, medida que atenta contra o livre exercício do direito de ação. (BRASIL, 2008)

Alguns autores entendem que a responsabilidade da

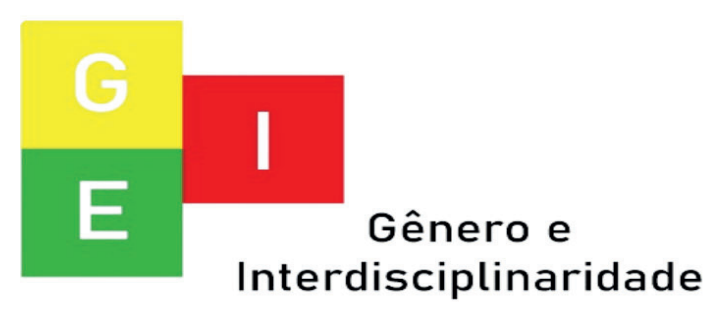


ISSN: 2675-7451

Vol. 02 - n 03 - ano 2021

Editora Acadêmica Periodicojs

genitora deve permanecer objetiva atinente aos danos morais e materiais suportados pelo suposto pai conforme, o teor do artigo que foi vetado.

\section{Rolf Madaleno (2019, p.}

77) aduz que, "Contudo, tal veto não descarta ser apurada a responsabilidade subjetiva da autora da ação, uma vez provado o dolo ou a culpa ao apontar o réu indevidamente como sendo o genitor do nascituro".

Importa salientar, que a dita discussão que envolve o presente subtópico está diretamente atrelada aos alimentos destinados ao nascituro seguirem muitas características dos alimentos, especialmente a irrepetibilidade ou a irrestituibilidade, que como dispõe Maria Berenice Dias:

Como se trata de verba que serve para garantir a vida e a aquisição de bens de consumo, inimaginá- vel pretender que sejam devolvidos. [...] Admite-se a devolução exclusivamente quando comprovado que houve má-fé ou postura maliciosa do credor. Em nome da irrepetibilidade, não é possível dar ensejo ao enriquecimento injustificado (CC 884). É o que se vem chamando de relatividade da não restituição. (DIAS, 2016, p. 949-950)

Nesta senda, o entendimento de Rodolfo Pamplona/ Pablo Stolze (2019, p. 727) no que tange a irrepetibilidade dos alimentos é que, “[...] já se admite, hoje, alguma flexibilidade em tal característica, de forma a repelir a litigância de má-fé."

O Desembargador Relator Ronei Danielli do TJ de SC, $6^{\mathrm{a}}$ Câmara Cível, em agravo de instrumento $\mathrm{n}^{\circ}$ 2013.002438-5, que

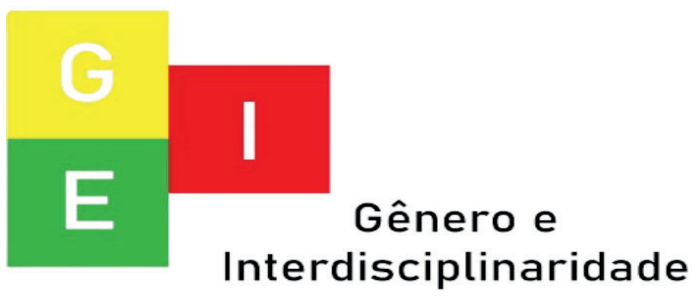


ISSN: 2675-7451

Vol. 02 - n 03 - ano 2021

Editora Acadêmica Periodicojs

foi julgado em 18/04/2013, traz

que "[...] pode o julgador embasar

sua convicção de paternidade em

meros indícios, ressalvando que,

em casos de comprovada má-fé

da gestante, também o princípio

da irrepetibilidade dos alimentos

pode sofrer ponderação."

Leciona Douglas

Phillips Freitas que:

Além da má-fé (multa por litigância ímproba), pode a autora (gestante) ser também condenada por danos materiais e/ou morais se provado que ao invés de apenas exercitar regularmente seu direito, esta sabia que o suposto pai realmente não o era, mas se valeu do instituto para lograr um auxílio financeiro de terceiro inocente. Isto, sem dúvidas, se ocorrer, é abuso de direito (art. 187 do CC), que nada mais é, senão, o exercício irregular de um direito, que, por força do próprio artigo e do art. 927 do $\mathrm{CC}$, equipara-se ao ato ilícito e torna-se fundamento para a responsabilidade civil. (FREITAS, 2009, p. 90)

\section{Carlos Roberto Gonçal-} ves denota sobre a tangibilidade do pleito de dano material e moral para o suposto genitor, mas põe algumas ressalvas, veja-se a seguir:

[...] embora afastada a responsabilidade objetiva da autora da ação, resta a possibilidade de ser esta responsabilizada com base no art. 186 do Código Civil, que exige [...] prova de dolo ou da culpa em sentido estrito do causador do dano. O problema é que, neste caso, qualquer grau de culpa,

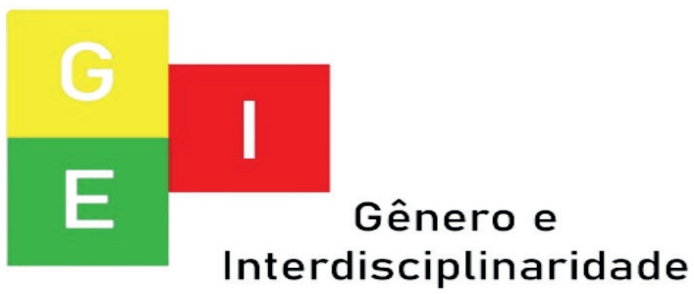


ISSN: 2675-7451

Vol. 02 - n 03 - ano 2021

Editora Acadêmica Periodicojs

mesmo a levíssima, pode ser considerada pelo julgador [...] o que poderia desencorajar a mulher grávida de propor ação de alimentos gravídicos, para não correr o risco de, no caso de insucesso da empreitada, vir a ser condenada a indenizar o suposto pai. [...] Deve-se aplicar o mesmo critério recomendado para o caso de oposição, de má-fé [...] Somente o dolo ou culpa grave serviriam de fundamento para a sentença condenatória. (GONÇALVES, 2017, p. 756-757)

Nota-se que, Maria Berenice Dias, Rolf Madaleno, Rodolfo Pamplona/Pablo Stolze, Douglas Freitas, Carlos Roberto Gonçalves e, o Desembargador Ronei Danielli, não divergem atinente à possibilidade de danos materiais e morais em desfavor da genitora quando comprovada a sua má-fé, essa por corolário fere diretamente o princípio da boa-fé que está agasalhado no art. 187 do CC/02.

Para Nogueira, o dano moral pode ser pleiteado, já o dano material não, mesmo se comprovada a má-fé da mãe, pois uma vez pago os alimentos, estes não serão repetíveis, também havendo um atentado contra o direito de ação. (NOGUEIRA, 2017, p.2).

\section{Rodolfo Pamplona/}

Pablo Stolze (2019, p. 740) trazem que, o dano material também pode ser pleiteado por responsabilidade objetiva, isto é, independente de culpa, "se a paternidade, posteriormente, for oficialmente negada, poderá o suposto pai voltar-se, em sede de ação de regresso, contra o verdadeiro genitor, para evitar o seu enriquecimento

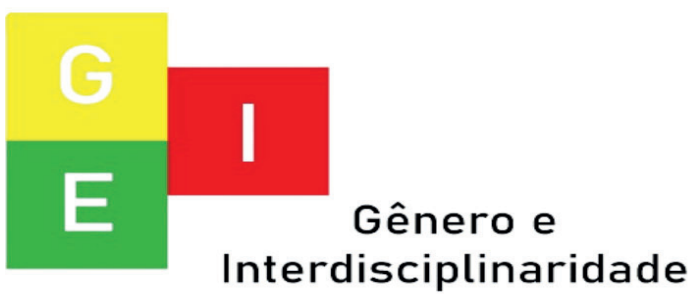


ISSN: 2675-7451

Vol. 02 - n 03 - ano 2021

Editora Acadêmica Periodicojs

sem causa". -la. (FILHO, 2011)

Nixon Duarte Filho, denota a possibilidade de prestação

O TJ de SP julgou parde caução pela genitora, como forma de assegurar os direitos do “não-pai”, a seguir:

[...] estipulação de caução no "límine" da demanda, como forma de resguardar direitos do réu que possa estar sendo submetido injustamente ao pagamento dos alimentos. Poderá o magistrado condicionar o pagamento de alimentos gravídicos ao oferecimento de caução idônea pela gestante. Deverá a autora garantir o juízo para poder receber qualquer tipo de subsídio do alimentante. Note-se que esta solução nem sempre será compatível com a situação econômica da acionante, porém, em sendo possível, poderá o juiz exigi-

cialmente procedente ação de reparação de danos morais e materiais advindas de atribuição indevida de paternidade, concedendo apenas os danos morais ao "não-pai", mesmo sem ter sido demonstrada a culpa ou dolo da genitora, vejamos:

Responsabilidade civil - Ação indenizatória (danos materiais e morais decorrentes de atribuição indevida de paternidade) - Procedência em parte, com verba reparatória fixada em R\$ 15.000,00 - Inconformismo - Acolhimento - Elementos de convicção que não revelam o dolo, na conduta da apelante - Concepção havida à época em que perdurava o relacionamento entre as partes - A despeito do

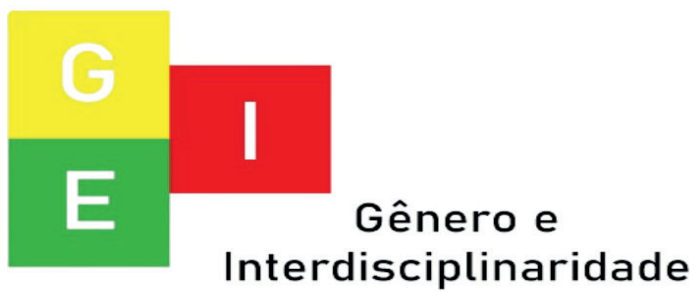


ISSN: 2675-7451

Vol. 02 - n 03 - ano 2021

presumido vexame

social por consequ-

ência da repercussão

do resultado negati-

vo do exame, o su-

posto envolvimento

extraconjugal, por si

só, também não ca-

racteriza ilícito civil.

GRIFO NOSSO. (TJ

de SP. Apelação $n^{\circ}$ :

5294320128260360

SP 0007529-

43.2012.8.26.0360,

Relator: Min. Grava

Brazil. $\quad 8^{\mathrm{a}}$ Câmara

de Direito Privado.

Data do julgamento:

05/02/2014)

Há entendimento juris-

prudencial manifesto pela proce-

dência da repetição do indébito

em casos de alimentos comuns,

lei 5.478/68, devendo servir de

parâmetro para futuras decisões

acerca da restituição dos danos

materiais nos alimentos gravídi-

cos:

ALIMENTOS. REPETIÇÃO DE IN-
Editora Acadêmica Periodicojs

DÉBITO. INDU-

ÇÃO EM ERRO.

Inexistência de fi-

liação declarada em

sentença. Enriqueci-

mento sem causa do

menor inocorrente.

Pretensão que deve

ser deduzida contra

a mãe ou contra o pai

biológico, responsá-

veis pela manuten-

ção do alimentário.

Restituição por este

não é devida. Aquele

que fornece alimen-

tos pensando errada-

mente que os devia

pode exigir a restitui-

ção do seu valor do

terceiro que realmen-

te devia fornecê-los.

GRIFO NOSSO.

(TJ de SP. Apelação

$n^{\circ}: 248 / 25$. Relator:

De. Luiz Antonio de

Godoy. $1^{\text {a }}$ Câmara

de Direito Privado.

Data do julgamento:

24/01/2007)

Diante de todo o expos-

to, como melhor forma de solu-

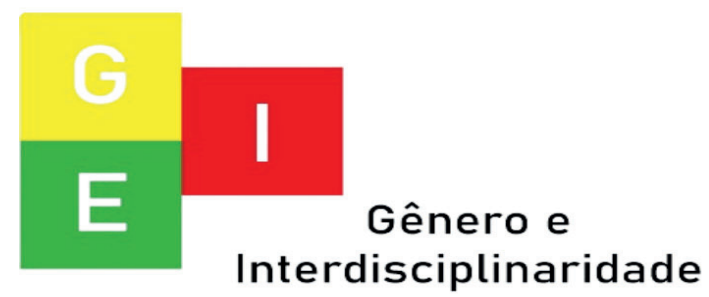


ISSN: 2675-7451

Vol. 02 - n 03 - ano 2021

Editora Acadêmica Periodicojs

cionar o conflito e resguardar os direitos e a dignidade da pessoa humana do "não-pai", a restituição do dano material é imprescindível, tendo em vista que ele arcou com um dever indevido. Assim, a mãe deverá responder objetivamente, consoante o art. 927, parágrafo único do $\mathrm{CC} / 02$ e, poderá entrar com ação de regresso em desfavor do verdadeiro pai, se este for encontrado.

Por fim, resta cristalino que a falsa acusação de paternidade sempre irá acarretar transtornos emocionais e abalo anímico, visto que o homem cria uma expectativa de paternidade por um longo tempo, podendo ocasionar também danos à imagem, à honra, logo o dano moral é evidente. Entretanto, o seu pleito com base na responsabilidade objetiva, fere o direito de ação da genitora. Dessa forma, obedecendo o princípio da proporcionalidade e da razoabilidade, se verificada a má-fé por culpa grave ou dolo da mãe, conforme os arts. 186, 187 e 927, caput do $\mathrm{CC} / 02$, a genitora deverá arcar com multa por litigância ímproba e danos morais, para que sirva de exemplo à outras genitoras e estas não se aproveitem da situação como meio de enriquecimento ilícito.

\section{CONSIDERAÇÕES FINAIS}

Diante de todo o exposto, evidente que a teoria concepcionista é a que melhor se adequa à proteção do nascituro, visto que quebra o paradigma do ser ainda não nascido, que passa de mero expectador a titular de direitos.

Nesta senda, o STJ vem garantindo uma diversidade de direitos ao nascituro, principalmente o direito aos alimentos, que é o núcleo da presente pesquisa e já possui legislação espe-

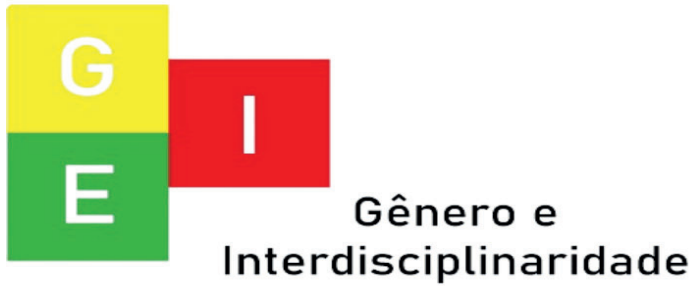


ISSN: 2675-7451

Vol. 02 - n 03 - ano 2021

Editora Acadêmica Periodicojs

cífica, chamada de lei de alimentos gravídicos.

Nota-se que, é pacífico o entendimento de que são devidos alimentos ao nascituro, como forma de concretizar o direito constitucional à vida e os princípios da dignidade da pessoa humana, da paternidade responsável, da solidariedade familiar e do melhor interesse da criança. Dessa forma, o teor legal que envolve o tema demonstra um avanço, ao delinear sobre um direito que já vinha sendo concedido nas práxis jurídicas.

Entretanto, como a supramencionada lei foi promulgada e seus artigos vetados parcialmente, ficam evidentes que algumas lacunas pairam ao seu redor, sendo que o atual trabalho tenta deslindá-las ao trazer possíveis e fundamentadas soluções.

A primeira lacuna é referente aos indícios de paterni- dade que geram bastante controvérsia, sendo que o magistrado, mesmo em sede de cognição sumária, deve se embasar naqueles e em exame comprobatório de gravidez. É pautado nisso que há eventual concessão de alimentos gravídicos, e não somente no mero requerimento da autora.

Vale destacar que, segundo a doutrina, os citados indícios são fotos, mensagens, entre outros. Todavia, considerando o direito de envergadura maior a ser resguardado e a segurança jurídica que situações da espécie demandam, ao menos deveria constar na lei algumas exemplificações dos indícios para a decisão não ficar a bel prazer nas mãos do magistrado. Dessa forma, resta cristalino que havendo os indícios de paternidade, o juiz deve deferir os alimentos ao nascituro.

No tocante à legitimi-

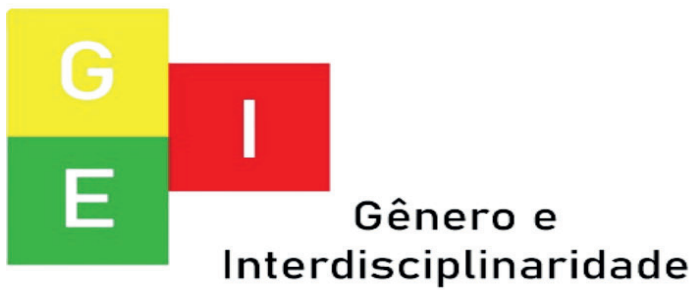


ISSN: 2675-7451

Vol. 02 - n 03 - ano 2021

Editora Acadêmica Periodicojs

dade ativa, a lei é controversa, pois dispõe na literalidade que o direito é da gestante de pleitear os alimentos gravídicos, muito embora ela só estivesse legitimada à propositura da ação por estar grávida, tendo em vista que a concepção é o único vínculo jurídico que enlaça as partes neste processo, logo o ser ainda não nascido que deveria ser o titular dessa verba.

Com relação à legitimidade passiva, deveria ser dos supostos pais, se a mãe não pudesse indicar somente um genitor e, englobar seus familiares caso o suposto pai seja falecido ou não tenha poder aquisitivo suficiente para arcar com a totalidade dos alimentos, já que não há obstáculo na ampliação do instituto, pois as regras da pensão alimentícia são utilizadas subsidiariamente.

Atinente ao termo inicial da obrigação de prestar ali- mentos gravídicos, sem sombra de dúvidas deve ser desde a concepção, visto que as todas as despesas devem ser compartilhadas entre a mãe e o suposto pai do início da gravidez ao parto.

No âmbito da (ir)retroatividade dos alimentos gravídicos diante da não concessão e posterior comprovação de paternidade, irrefutável que eles devem retroagir desde a concepção, haja vista que seria demasiadamente injusto a genitora não ser ressarcida, pois como já foi dito as despesas entre os genitores devem ser divididas.

$\mathrm{Na}$ esfera da (im)possibilidade de exigência de danos morais e/ou materiais pelo "não pai”, há demasiada discussão. Entende-se que se após o nascimento da criança, for comprovado que o suposto pai que arcou com os alimentos, na verdade não é o biológico, a concessão

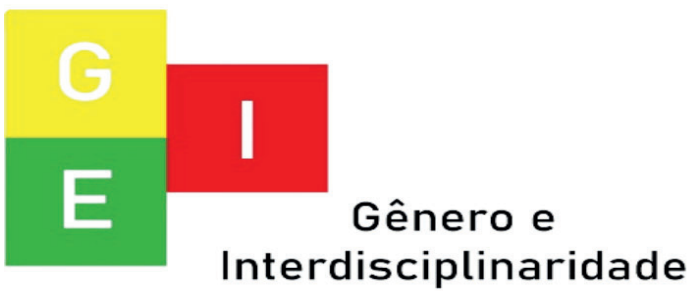


ISSN: 2675-7451

Vol. 02 - n 03 - ano 2021

Editora Acadêmica Periodicojs

do dano material deve ser inequívoca. Desta maneira, a genitora deverá ser responsabilizada objetivamente, ou seja, independente de culpa e, poderá ingressar com ação de regresso em face do pai biológico, se este for encontrado.

Observa-se que, não se pode deixar de olvidar que a condenação injusta de um suposto genitor acarreta repercussão na sua vida, pois tem a sua expectativa de ser pai frustrada e, até mesmo a possibilidade de ter sua honra e imagem machadas. Com isso, o dano moral é sempre visível. Porém, o pleito do "não pai" através da responsabilização objetiva da genitora, fere o direito de ação dela. Assim, com base no princípio da proporcionalidade e da razoabilidade, o dano moral só deve ser concedido se for demonstrada a má-fé por culpa grave ou dolo da mãe. Logo, a responsabilidade da genitora é subjetiva e, ela deverá pagar além de danos morais, multa por litigância ímproba.

Por fim, crível destacar que tal análise não pode findar por aqui. Visto que, o conhecimento a respeito do tema é muito mais extenso e as demandas processuais atreladas ao assunto não param de abarrotar o judiciário, para tanto este precisa estar atento a lacunosidade da lei de alimentos gravídicos e, tomar medidas para supri-las, sendo que algumas das soluções o presente trabalho teve o fito de expor.

\section{REFERÊNCIAS}

BRASIL. Constituição da República Federativa do Brasil de 1988. Brasília, DF: Presidência da República, [2016]. Disponível em: $\quad<$ http://www.planalto.gov.

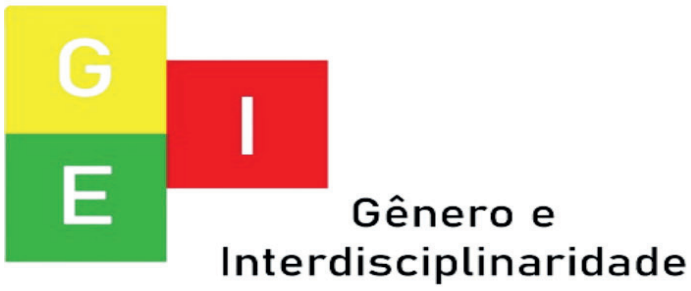


ISSN: 2675-7451

Vol. 02 - n 03 - ano 2021

Editora Acadêmica Periodicojs

br/ccivil_03/Constituicao/ Cons- jus.br/enunciados/>. Acesso em:

tituiçao.htm. >. Acesso em: 1501 mai. 2020.

mar. 2020.

BRASIL. Decreto ${ }^{\circ} 28$ de 14 de

BRASIL. Estatuto da Criança e setembro de 1990. Dispõe acerca do Adolescente. Brasília, DF: Seda Convenção sobre os Direitos nado Federal, 1990. Disponível da Criança, de 02 de setembro de 1990. Disponível em: <http:// em: <http://www.planalto.gov.br/ ccivil_03/leis/18069.htm>. AcesWww.planalto.gov.br/ccivil_03/ so em: 15 mar. 2020.

decreto/1990-1994/D99710. htm>. Acesso em: 15 mar. 2020.

BRASIL. Decreto no 678 de 6 de novembro de 1992. Dispõe sobre a Convenção Americana sobre Direitos Humanos (Pacto de São José da Costa Rica), de 22 de novembro de 1969. Disponível em: < http://www.planalto.gov.br/ ccivil_03/decreto/D0678.htm>. Acesso em: 15 mar. 2020.

BRASIL. Enunciado n. 522. V Jornada de Direito Civil. Organização Ministro Ruy Rosado de Aguiar Jr. Brasília: CJF, 2012. Disponível em: $<$ https://www.cjf.

BRASIL. Lei n. ${ }^{\circ} 11.804$, de 5 de novembro de 2008. Disciplina o direito a alimentos gravídicos e a forma como ele será exercido e dá outras providências. Disponível em: <http://www.planalto.gov.br/ ccivil_03/_Ato2007-2010/2008/ Lei/L11804.htm>. Acesso em: 15 mar. 2020.

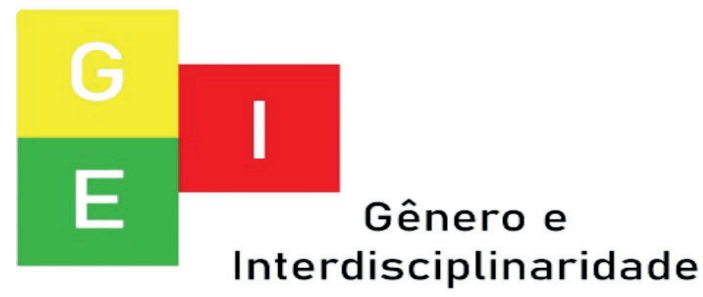


ISSN: 2675-7451

Vol. 02 - n 03 - ano 2021

Editora Acadêmica Periodicojs $\mathrm{ta}=20130828 \&$ formato $=\mathrm{PDF}>$.

BRASIL. Lei $\mathrm{n}^{\mathrm{o}}$ 13.105, de Acesso em: 20 mar. 2020.

16 de março de 2015. Institui

o Código de Processo Civil. BRASIL. Superior Tribunal Disponível em: <http:// de Justiça. Recurso Especial n. www.planalto.gov.br/ccivil_03/__ 1194059 - SP 2010/0085808-2. Ato2015- 2018/2015/Lei/L13105. Rel. Min. M a s s a htm>. Acesso em: 15 mar. 2020. mi Uyeda. 6 n o v .

2012. Disponível e $\mathrm{m}$ : BRASIL. Mensagem no 853, de <https://stj.jusbrasil.com.br/ 5 de novembro de 2008. Planalto. jurisprudencia/22665055/reDisponível em: $<$ http://www.pla- curso-especial-resp-1194059-spnalto.gov.br/ccivil_03/_ato2007- 2010-0085808-2-stj/inteiro-te2010/2008/Msg/VEP-853-08. or-22665056>. Acesso em: 01 htm>. Acesso em: 15 mar. $2020 . \quad$ abr. 2020.

BRASIL. Superior Tribunal BRASIL. Superior Tribunal de Justiça. Recurso Especial n. de Justiça. Recurso Especial n. 1170239 - RJ 2009/0240262-7. 1415727 - SC 2013/0360491-3. Rel. Min. Marco Buzzi. 28 ago. Rel. Min. Luis F e 1 i 2013. Disponível em: $\quad$ pe $\quad$ Salomão. $\quad 2 \quad 9$ $<$ https://ww2.stj.jus.br/pro- set. 2014. Disponível cesso/revista/documento/ em: <https://ww2.stj.jus.br/ mediado/? componente $=I-\quad$ processo/revista/documento/ TA\&sequencial $=1231792 \&$ num__ mediado $/$ ?componente $=$ ITA\& registro $=200902402627 \& d a-\quad$ sequencial $=1346306 \&$ num_re-

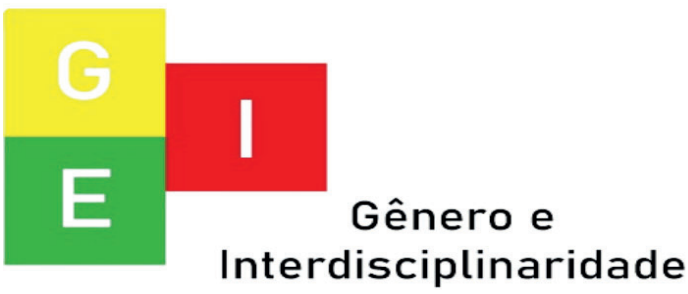


ISSN: $2675-7451$

Vol. 02 - n 03 - ano 2021

Editora Acadêmica Periodicojs

gistro $=201303604913 \&$ da $-\quad$ comentada. Disponível em: $<$ ht$\mathrm{ta}=20140929 \&$ formato $=\mathrm{PDF}>. \quad \mathrm{tps}: / / \mathrm{www}$. dizerodireito.com. Acesso em: 20 mar. 2020.

br/2017/11/sumula-596-do-stj-comentada.html?m=1>. Acesso em:

BRASIL. Superior Tribunal 26 mar. 2020.

de Justiça. Recurso Especial

n. 1629423 SP 2016/0185652-7. BRASIL. Supremo Tribunal de Rel. Min. M a r c o Justiça. Jurisprudência reconheAurélio Bellizze. 28 ce direitos e limites à proteção abr. 2017. Disponível jurídica do nascituro. em: $\quad<$ https://www.google. Disponível em: $<$ http://www. com/amp/s/stj.jusbrasil.com. stj.jus.br/sites/portalp/Paginas/ br/jurisprudencia/465607500/ Comunicacao/Noticias/Jurisprurecurso- $\quad$ especial-resp- dencia-reconhece- direitos-e-li-1629423-sp-2016-0185652-7/ mites-a-protecao-juridica-doamp>. Acesso em: 10 abr. 2020. -nascituro.aspx>. Acesso em: 15 mar. 2020.

BRASIL. Superior Tribunal de Justiça. Súmula $n^{\circ} .277$ do STJ CAHALI, Yussef Said. Dos ali(anotada). Disponível em: $<$ http:// mentos. 3. ed. São Paulo: Editora www.crianca.mppr.mp.br/pagiRevista dos Tribunais, 1998.

na-1286.html>. Acesso em: 28 CAMARGO, Diego Guimarães. mar. 2020.

A teoria adotada pelo Código Civil acerca do início da perBRASIL. Superior Tribunal de sonalidade da pessoa natural: Justiça. Súmula nº 596 do STJ uma análise à luz da doutrina

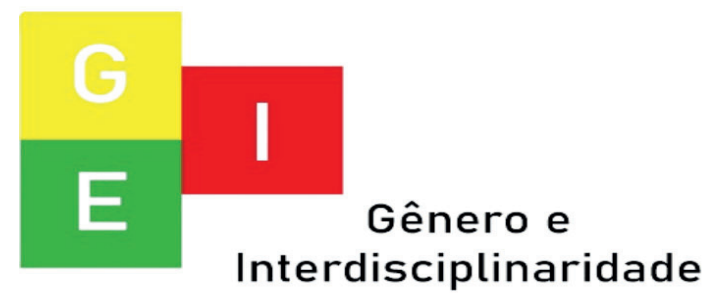


e da jurisprudência do Superio Tribunal de Justiça. Disponível em: $<$ http://www. conteudojuridico.com.br/consulta/Artigos/>. Acesso em: 15 abr. 2020.

CHINELLATO, Silmara Juny, MACHADO, Costa. Código Civil interpretado: artigo por artigo, parágrafo por parágrafo. 10 . ed. - Barueri, SP: Manole, 2017.

COSTA, Talita Mie Gonçalves; MOTA, Karine Alves Gonçalves. O abuso de direito nas ações de alimentos gravídicos decorrente da negativa de paternidade. Disponível em: <https:// ambitojuridico.com.br/cadernos/ direito-civil/o-abuso-de-direito-nas-acoes-de- alimentos-gravidicos-decorrente-da-negativa-de paternidade/>. Acesso em: 01 mai. 2020.
DIAS, Maria Berenice. Manual de direito das famílias. [Livro eletrônico]. 4. ed. São Paulo: Revista dos Tribunais, 2016.

DONA, Géssica Amorim. Os alimentos gravídicos e a possibilidade de indenização ao suposto pai quando da não confirmação da paternidade. Disponível em: $<$ https://ambitojuridico.com.br/ edicoes/revista-103/os-alimentos-gravidicos-e-a possibilidadede-indenizacao-ao-suposto-pai-quando-da-nao-confirmacao-da paternidade/\#_ftn12>. Acesso em: 01 mai. 2020.

DONOSO, Denis. Alimentos Gravídicos: aspectos Materiais e Processuais da Lei $\mathrm{n}^{\circ}$. 11.804/2008. Revista IOB de Direito de Família. São Paulo: v. 11, n. 56, p. 101-111, out. /nov., 2009.

FERNANDES, José Neto Fains-

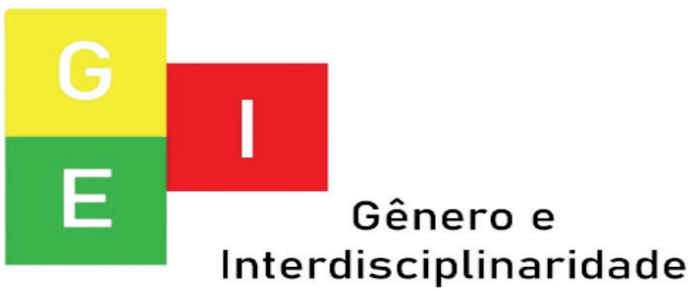


ISSN: 2675-7451

Vol. 02 - n 03 - ano 2021

Editora Acadêmica Periodicojs

tein. Os alimentos gravídicos lise-da-lei-11-804- 08/amp/>.

e a relativização do princípio Acesso em: 15 mai. 2020.

da irrepetibilidade ante à fra-

gilidade da Lei 11.804/2008. FONSECA, Fernando Gajardoni

Disponível em: < https://www. da. O livre convencimento moti-

google.pt/url?sa=t\&source=we- $\quad$ vado não acabou no novo CPC.

b\&rct=j\&url=https://revistas. Disponível em: < https://www.

unifacs.br/index.php/redu/ar- jota.info/paywall?redirect_to=//

ticle/download/1361/1048\&- www.jota.info/opiniao-e- anali-

ved=2 ahUKEwj3 iqPa9M - se/artigos/o-livre-convencimen-

PpAhUBJrkGHSrqB0YQFjAAe to-motivado-nao-acabou-no-no-

gQIAxAB\&usg=AOvVaw0k- vo-cpc-06042015>. Acesso em:

95JbPh53nDusUEndVEvF>. $\quad 25$ abr. 2020.

Acesso em: 01 mai. 2020.

FERREIRA FILHO, Nixon Du-

FREITAS, Douglas Phillips.

arte Muniz. Repetição de ali-

Alimentos gravídicos e a Lei

mentos gravídicos em face da

11.804/2008: Primeiros reflexos.

inexistência de vínculo paterno

Disponível em: <www.ibdfam.

filial. Análise da Lei 11.804/08.

org.br/?artigos \&artigo $=468>$.

Acesso em: 20 mar. 2020.

Disponível em: <https://www.

google.pt/amp/s/ambitojuridi-

co.com.br/edicoes/revista-83/

Alimentos gravídicos e

repeticao-de- alimentos-gravi-

a lei $\quad n^{\circ} \quad 11.804 / 08$.

dicos-em-face-da-inexistencia-

Disponível em:

-de-vinculo-paterno-filial-ana-

$<$ https://periodicos.processus.

com.br/index.php/egjf/article/

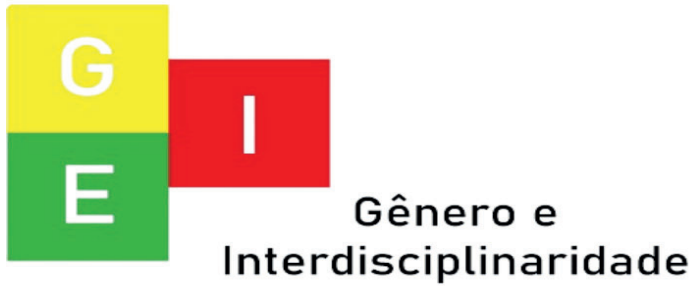


view/18>. Acesso em: 20 mar. 2020

GAGLIANO, Pablo Stolze; FILHO, Rodolfo Pamplona. Novo curso de direito civil, v.6: direito de família. 9. ed. - São Paulo: Saraiva, 2019.

GOIÁS. Tribunal de Justiça. Apelação Cível n 0297998592017809006. Rel. De. Alan Sebastião de $\quad \mathrm{S}$ e $\mathrm{n}$ a Conceição. $\quad 22 \quad \mathrm{~m} \quad \mathrm{a} \quad \mathrm{r}$. 2019. Disponível e $\mathrm{m}$ :

$<$ https://tj- $\quad$ go.jusbrasil.com.br/ jurisprudencia/712781778/apelacao-cpc-2979985920178090006/ inteiro- teor-712781779?ref=juris-tabs>. Acesso em: 25 mar. 2020.

GONÇALVES, Carlos Roberto. Direito civil brasileiro. v.6: direito de família.14. ed. São Paulo: Saraiva, 2017.
LEITE, Gisele Pereira Jorge.

Comentários à Lei 11.804/2008

(Alimentos Gravídicos). Disponível em: $\quad<$ http://www.ambitojuridico.com.br/site/index. php?n_link=revista_artigos_leitura\&artigo_id $=6120>$. Acesso em: 22 mar. 2020.

LOMEU, Leandro Soares. Alimentos Gravídicos Avoengos. Disponível em: <http://www.ibdfam.org.br/ artigos/505/Alimentos+Grav\%C3\%ADdicos + Avoengos $>$. Acesso em: 30 mar. 2020.

LOMEU, Leandro Soares. Alimentos gravídicos: aspectos da Lei $n^{\circ} 11.804 / 2008$. Revista IOB de Direito de Família, v. 9, n. 51, p. 24-29, dez. 2008/jan. 2009.

LUZ, Felipe. Alimentos gravídicos: a (des)necessidade da lei $\mathrm{n}$. 11.804/2008. Disponível em: $<$ ht-

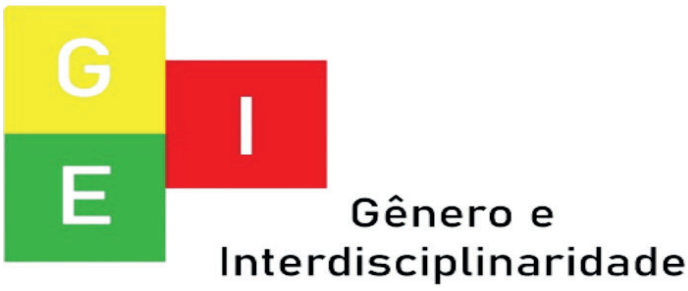


ISSN: 2675-7451

Vol. 02 - n 03 - ano 2021

Editora Acadêmica Periodicojs

tps://repositorio.ufsc.br>. Acesso em: 18 mar. 2020.

MACHADO, Marina Girão de Oliveira. A concessão de alimentos gravídicos: uma análise crítica sobre a 1 e i 11.804/2008. Disponível em: < https://www.google.pt/url?sa $=$ t\& source $=$ we$\mathrm{b} \& \mathrm{rct}=\mathrm{j} \& \mathrm{url}=\mathrm{http}: / / \mathrm{www}$. mpce.mp.br/wpcontent/ uploads/2018/12/ARTIGO6.pdf\&ved $=2$ ahUKEwjZ6dv2s8HpAhVIHLkGHakoAcUQFjAAeg QIAxAB\&usg=AOvVaw2ovtcRv0E_mnSW4MdiHgad $>$. Acesso em: 15 mar. 2020.

MADALENO, Rolf. Manual de Direito de Família. 2. ed. Rio de Janeiro: Forense, 2019. MARQUES, Maria Isabel Ferreira. Alimentos gravídicos: aspectos polêmicos. Disponível em: $<$ http://revista.direitofranca.br/ index.php/refdf/article/view/707/

pdf $>$. Acesso em: 18 mar.

2020.

MARTINS, Fabiane Parente Teixeira. Algumas considerações sobre a lei que disciplina os alimentos gravídicos. Disponível em: $<$ http://www.ibdfam. org.br/artigos/552/Algumas+considerações + sobre $+a+l e i+q u e+-$ disciplina + os + alimentos + gravídicos>. Acesso em: 20 mar. 2020.

MASSARA, Geruza Ramos; Alimentos gravídicos: responsabilidade civil da genitora decorrente da negativa de paternidade. Disponível em: $<$ https://ambitojuridico.com. br/edicoes/revista-101/alimentos-gravidicos-responsabilidade- civil-da-genitora-decorrente-da-negativa-de-paternidade/>. Acesso em: 01 mai. 2020.

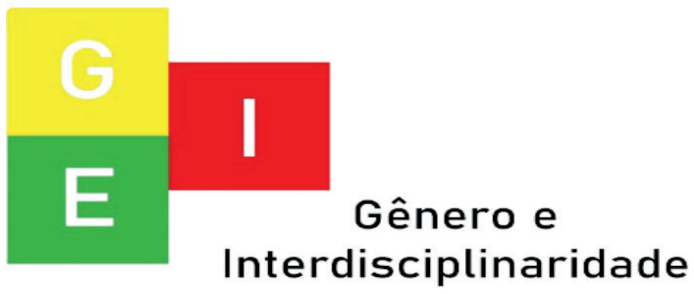


ISSN: 2675-7451

Vol. 02 - n 03 - ano 2021

Editora Acadêmica Periodicojs

NEGRÃO, Anny Gabrielle Frez. edicoes/revista-164/principio-daAção de investigação de paterni- paternidade-responsavel-e-suadade e o direito personalíssimo -aplicabilidade-na-obrigacao-alida criança em confronto com mentar/amp/>. Acesso em: 25 o direito do suposto pai. Dis- mar. 2020.

ponível em: $<$ https://facnopar. com.br/conteudo-arquivos/arquiPARANÁ. Tribunal de Jusvo-2017-06-14-14974735403464. tiça. Agravo de Instrumento pdf>. Acesso em: 01 mai. 2020.

n. 655.776-6. Rel. De. Costa Barros. Curitiba 17

NUNES, Bruna Carolino Ro- mar. 2010. Disponível

drigues. Alimentos gravídicos: em: <http://portal.tjpr.jus.br/juaspectos históricos e jurídicos. risprudencia/j/1921177/Decis\%Disponível em:<www.pucrs.br/ C3\%A3o\%20MonocrC3\%A1tidireito/wp-content/uploads/si- ca- 655776-6\#integra_1921177>. tes/11/2018/09/bruna_nunes.pdf_Acesso em: 30 mar. 2020.

> Acesso em: 20 mar. 2020.

RIO GRANDE DO SUL. TribuOLIVEIRA, Rafael Guimarães nal de Justiça. Agravo de Instrude; RANGEL, Tauã Lima Ver- mento n. 70080676984. Rel. De. dan. Princípio da paternidade José Antônio D a lto e responsável e $\quad \mathrm{s}$ u a Cezar. 20 ago. 2019. aplicabilidade na obrig a - Disponível em: ção alimentar. Disponí- <https://www.google.com/amp/s/ vel em: $<$ https://www.google. tjrs.jusbrasil.com.br/jurisprudenpt/amp/s/ambitojuridico.com.br/ cia/825255514/agravo-de- instru-

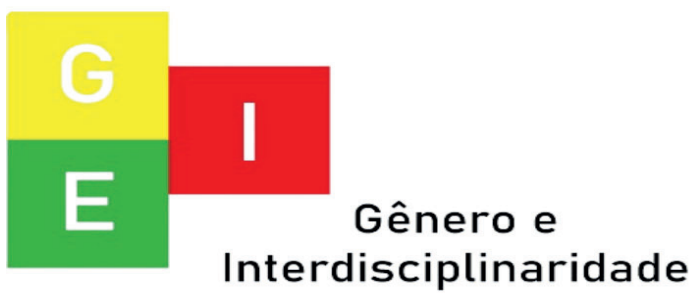


ISSN: 2675-7451

Vol. 02 - n 03 - ano 2021

Editora Acadêmica Periodicojs

mento-ai-70080676984-rs/amp>. Acesso em: 30 mar. 2020.

RIO GRANDE DO SUL. Tribunal de Justiça. Agravo de Instrumento n. 70082880873. Rel. De. Ricardo Moreira Lins Pastl. 8 nov. 2019. Disponível em: <https://www.google.com/ amp/s/tjrs.jusbrasil.com.br/jurisprudencia/781466605/agravo-deinstrumento-ai-70082880873-rs/ amp>. Acesso em: 04 mai. 2020.

RIO GRANDE DO SUL. Tribunal de Justiça. Apelação Cível n. 70077253714. Rel. De. Liselena Schifino Robles Ribeiro. 30 mai. 2018 .

Disponível em: $<$ https:// tj- rs.jusbrasil.com.br/jurisprudencia/585131359/apelacaocivelac70077253714rs?ref=legalquote-trigger $>$. Acesso em: 30 mar. 2020.
RIO GRANDE DO SUL.. Tribunal de Justiça. Apelação Cível n. 7008160391. Rel. De. Rui Portanova. 26 set. 2019. Disponível em: <https:// tj- rs.jusbrasil.com.br/jurisprudencia/773843073/apelacaocivelac70081660391rs? ref=serp $>$. Aces so em: 01 mai. 2020.

RIZZARDO, Arnaldo. Direitos de Família. 10. ed. Rio de Janeiro: Forense, 2019.

RODRIGUES, Lana Ramos de Oliveira. Alimentos gravídicos: responsabilidade civil decorrente de pagamento indevido de alimentos gravídicos. Disponível em: $<$ https://repositorio.unic eub.br/jspui/bitstream/235/11870/1/21338458.pdf $>$. Acesso em: 01 mai. 2020.

RODRIGUES, Paulo Octávio

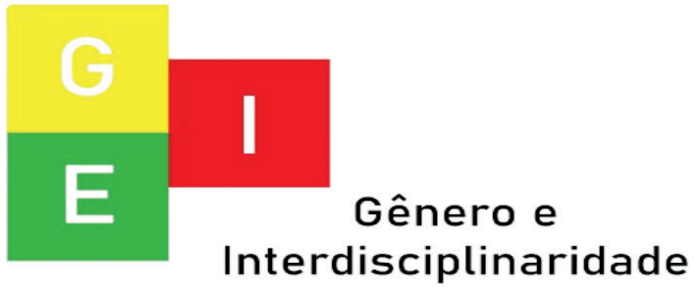


Montanari. Aspectos jurídicos dos alimentos gravídicos. Disponível em: $<$ https://www.google. com/amp/s/m.monografias.brasilescola.uol.com.br/amp/direito/ aspectos-jurIdicos-dos-alimentos-gravIdicos.htm>. Acesso em: 16 mar. 2020.

RONDÔNIA. Tribunal de Justiça. Apelação Cível n. $00077056520118220102 . \quad$ Rel. De. Raduan Miguel Filho. 22 out. 2013. Disponível em: <https://tj- ro.jusbrasil.com.br/jurisprudencia/295380465/apelap10118220102? ref $=$ juris-tabs $>$. Acesso em: 30 mar. 2020.

$\begin{array}{ll}\text { SANTA } & \text { CATARINA. } \\ \text { Tribunal } & \text { de Justiça. }\end{array}$
gravo de Instrumento $\mathrm{n}$. 40147105020198240000. Rel. De. Marcus Tulio Sartorato. 3 set. 2019. apud SANTA CATARINA. Tribunal de Justiça. Agravo de Instrumento n. 20130024385.

Rel. De. Ronei Danielli. 18

abr. 2013.Disponível

em: $<$ https://tj- sc.jusbrasil.com.

br/jurisprudencia/752652656/

agravodeinstrumentoai4014710502019824000 0-meleiro-4014710-5020198240000/ inteiro-teor-752652739? $\mathrm{ref}=\mathrm{fe}-$ ed>. Acesso em: 01 mai. 2020.

RIO GRANDE DO SUL.. Tribunal de Justiça. Apelação Cível n. 0056096020138240067. Rel. De. Luiz Felipe Schuch. 11 dez. 2017. Disponível em: < h t t p s :// tj- $\quad$ sc.jusbrasil.com.br/jurisprudencia/530642365/apelacao-civelac-56096020138240067-saomiguel-do-oeste-0005609-6020138240067/ inteiro-teor-530642412>. Acesso em: 30 mar. 2020.

SÃO PAULO. Tribunal de Justiça. Agravo de Instrumento $\mathrm{n}$.

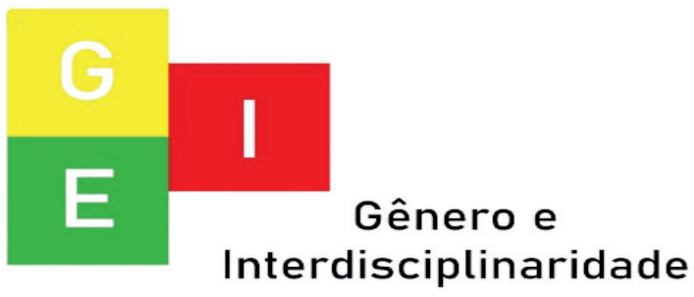


ISSN: $2675-7451$

Vol. 02 - n 03 - ano 2021

Editora Acadêmica Periodicojs

20130489420208260000. Rel. mentos gravídicos: o titular

De. Donegá Morandi- desse direito e a presunção juni. 9 mar. 2020 ris tantum de paternidaDisponível em: <https://j- de. Disponível e $\mathrm{m}$ : < sp.jusbrasil.com.br/jurispruden- https://www.google.pt/amp/s/ cia/819572018/agravodeinstru- ambitojuridico.com.br/edicoes/ mentoai2013048942020826000 revista-110/alimentos- gravidi0-sp-2013048-9420208260000/ cos-o-titular-desse-direito-e-ainteiro-teor-819572228?ref=ju- $\quad$-presuncao-juris-tantum-de-paris-tabs $>$. Acesso em: 20 mar. ternidade/amp/>. A c e s s o 2020.

em: 02 mai. 2020.

RIO GRANDE DO SUL.. TriSILVA, Nathan Lino da. Nascitubunal de Justiça. Apelação Cível ro: analisando suas especificidan. 000752943201282603600 . Rel. des. Disponível em: <https://jus. De. Grava Brazil. 05 com.br/artigos/27400/nasciturofev. 2014. Disponível -analisando-suas-especificidaem: <https://www.google.pt/ des>. Acesso em: 16 mar. 2020.

amp/s/tj- $\quad$ sp.jusbrasil.com.br/jurisprudencia/122410973/apelacaSIMÃO, José Fernando; TARo5294320128260360sp0007529$\begin{array}{llllllllllllll}4 & 3 & 2 & 0 & 1 & 2 & 8 & 2 & 6 & 0 & 3 & 6 & 0 & /\end{array}$ TUCE, Flávio. Direito Civil: diinteiro-teor-122410982/amp>. reito de Família. 6. ed. São Paulo: Acesso em: 20 mar. 2020.

SOUZA, Vanessa Ilana de. AliSILVA, Danúbia Cantieri. Ali- mentos gravídicos. Disponível

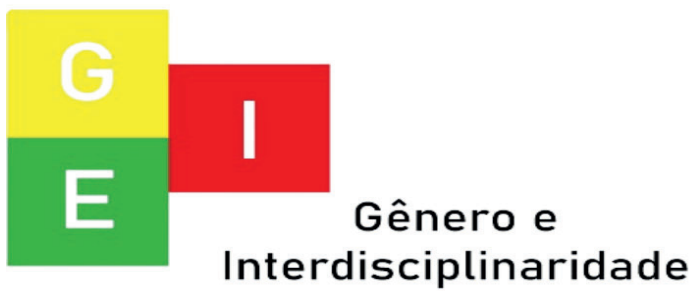


em: < https://lex.com.br/doutri- 15 mar. 2020.

na_27594407_ALIMENTOS_

GRAVIDICOS.aspx>. Acesso VENOSA, Sílvio de Salvo. Direi-

em: 18 mar. 2020.

to Civil: direito de família. 9. ed.

São Paulo: Atlas, 2009. VIEIRA,

TAMMENHAIN, Juliana Cabral Renata Alves Lima. Alimentos

De Oliveira. Alimentos gravídi- gravídicos. Disponível em: $<$ ht-

cos à luz do princípio da dignida-

tps://servicos.unitoledo.br/repo-

de da pessoa humana. sitorio/bitstream/7574/1724/1/

Disponível em: $\quad<$ https:// Renata\%20Alves\%20Lima\%

santacruz.br/revistas/index.php/ 20Vieira.pdf $>$. Acesso em: 15

JUSFARESC/article/view/1951>. mar. 2020.

Acesso em: 17 Marcos. 2020.

TARTUCE, Flávio. Direito Civil:

direito de Família. v. 5. $11^{\mathrm{a}}$ ed.

Rio de Janeiro: Forense, 2016.

TEDESKI, Juliane. Alimentos

gravídicos. Trabalho de Conclusão de Curso. Faculdade de Ciências Jurídicas da Universidade Tuiuti do Paraná. Disponível em: $<$ https://www.trabalhosfeitos. com/ensaios/Alimentos-Gravidi$\cos / 58816062 . h t m l>$. Acesso em:

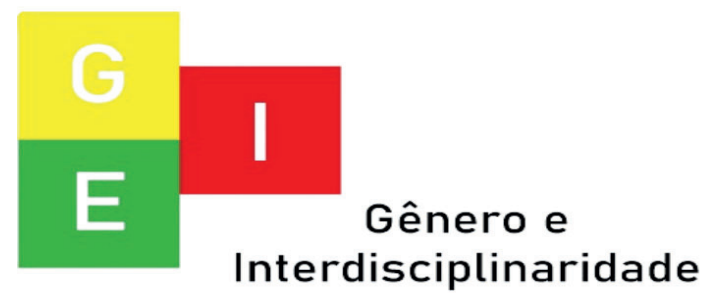

